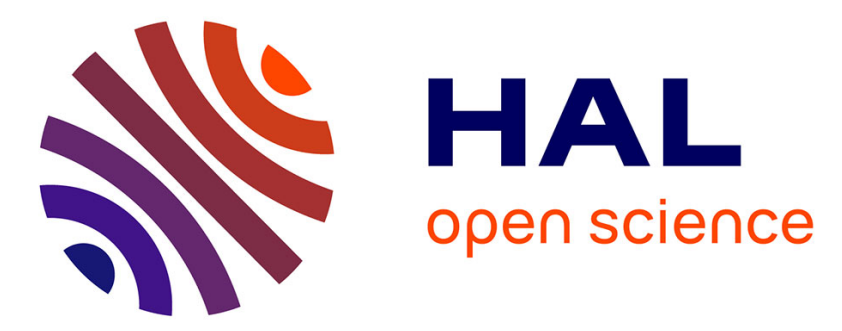

\title{
OLD INDUSTRIAL REGIONS IN EUROPE: A COMPARATIVE ASSESSMENT OF ECONOMIC PERFORMANCE
}

Kean Birch, Danny Mackinnon, Andrew Cumbers

\section{- To cite this version:}

Kean Birch, Danny Mackinnon, Andrew Cumbers. OLD INDUSTRIAL REGIONS IN EUROPE: A COMPARATIVE ASSESSMENT OF ECONOMIC PERFORMANCE. Regional Studies, 2010, 44 (01), pp.35-53. 10.1080/00343400802195147 . hal-00565124

\author{
HAL Id: hal-00565124 \\ https://hal.science/hal-00565124
}

Submitted on 11 Feb 2011

HAL is a multi-disciplinary open access archive for the deposit and dissemination of scientific research documents, whether they are published or not. The documents may come from teaching and research institutions in France or abroad, or from public or private research centers.
L'archive ouverte pluridisciplinaire HAL, est destinée au dépôt et à la diffusion de documents scientifiques de niveau recherche, publiés ou non, émanant des établissements d'enseignement et de recherche français ou étrangers, des laboratoires publics ou privés. 


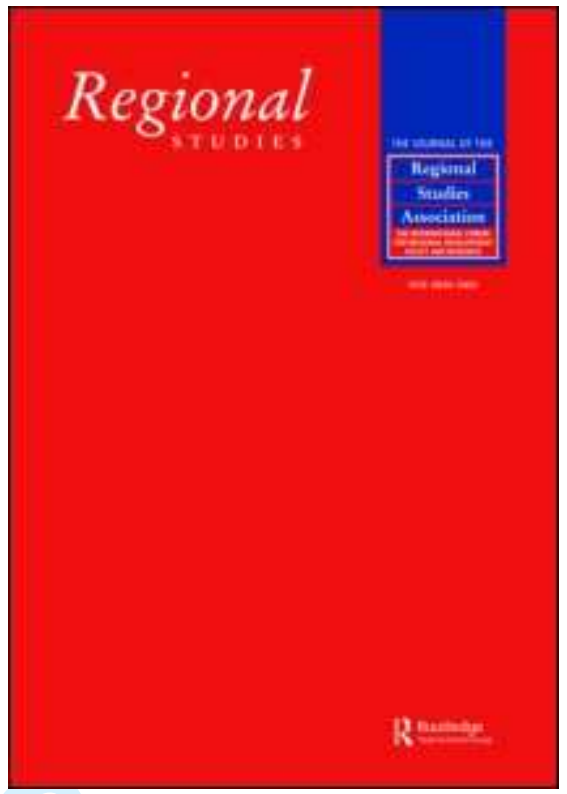

\section{OLD INDUSTRIAL REGIONS IN EUROPE: A COMPARATIVE ASSESSMENT OF ECONOMIC PERFORMANCE}

\begin{tabular}{|r|l|}
\hline Journal: & Regional Studies \\
\hline Manuscript ID: & CRES-2007-0065.R3 \\
\hline Manuscript Type: & Main Section \\
\hline JEL codes: & $\begin{array}{l}\text { N60 - General, International, or Comparative < N6 - Manufacturing } \\
\text { and Construction < N - Economic History, O18 - Regional, Urban, } \\
\text { and Rural Analyses < O1 - Economic Development < O - Economic } \\
\text { Development, Technological Change, and Growth, P52 - } \\
\text { Economic Systems < P - Economic Systems, R11 - Regional } \\
\text { Economic Activity: Growth, Development, and Changes < R1 - } \\
\text { General Regional Economics < R - Urban, Rural, and Regional } \\
\text { Economics }\end{array}$ \\
\hline \hline Keywords: & $\begin{array}{l}\text { Old industrial regions, Regional performance, The 'new } \\
\text { regionalism', Regional policy, Varieties of capitalism }\end{array}$ \\
\hline \hline
\end{tabular}

\section{SCHOLARONE" Manuscripts}




\title{
OLD INDUSTRIAL REGIONS IN EUROPE: A COMPARATIVE ASSESSMENT OF ECONOMIC PERFORMANCE
}

\author{
Kean Birch (corresponding) \\ Centre for Public Policy for Regions (CPPR) \\ University of Glasgow \\ Ivy Lodge \\ 63 Gibson Street \\ Glasgow \\ G12 8LR
}

kean.birch@lbss.gla.ac.uk

Danny MacKinnon

Department of Geography

University of Aberdeen

Elphinstone Road

Aberdeen

AB24 3UF

danny.mackinnon@abdn.ac.uk

Andrew Cumbers

Department of Geographical and Environmental Sciences

University of Glasgow 
East Quadrangle
University Avenue
Glasgow
G12 8QQ
Andrew.Cumbers@ges.gla.ac.uk

First received: March 2007

Accepted: February 2008

\begin{abstract}
Recent academic and policy discourses on regional development in Europe promote the expansion of 'knowledge-based' economies and learning regions. The assumptions underpinning the new regional policy are cast into sharp focus by the experiences of old industrial regions (OIRs). We engage with these issues through empirical research into the recent fortunes of OIRs in Western Europe, drawing upon material from the Eurostat database. Our findings highlight diverse experiences among these OIRs. This raise questions about the role of different national varieties of capitalism in shaping regional trajectories and the different mechanisms of regional adaptation promoted in the different countries.
\end{abstract}

KEYWORDS: Old industrial regions; regional performance; the 'new regionalism'; regional policy; varieties of capitalism. 
JEL: N60; O18; P52; R11

Les anciennes régions européennes à vocation industrielle: une évaluation comparative de la performance économique.

Birch et al.

Des discours théoriques et de politique récents sur l'aménagement du territoire en Europe prône le développement des économies 'de la conniassance' et des régions d'apprentissage. Les hypothèses qui étayent la nouvelle politique régionale sont mis nettement en relief par l'histoire des anciennes régions à vocation industrielle. On aborde ces questions en se lancant dans des recherches empiriques quant à la performance récente des anciennes régions à vocation industrielle en Europe de l'Ouest, puisant dans la documentation provenant de la base de données d'Eurostat. Les résultats soulignent les différentes expériences de ces anciennes régions à vocation industrielle. Cela soulève des questions quant au rôle des divers genres nationaux de capitalisme dans la construction des trajectoires régionales et les différents mécanismes d'adaptation régionale mis en avant dans les divers pays.

Anciennes régions à vocation industrielle / Performance régionale / Nouveau 'régionalisme' / Politique régionale / Genres de capitalisme

Classement JEL: N60; O18; P52; R11

\section{Alte Industrieregionen in Europa: eine vergleichende Bewertung der Wirtschaftsleistung}

Kean Birch, Danny MacKinnon and Andrew Cumbers

\section{ABSTRACT}

In den aktuellen akademischen und politischen Diskursen über Regionalentwicklung in Europa wird eine Expansion der 'wissensbasierten' Ökonomien und Lernregionen gefordert. Die der neuen Regionalpolitik zugrundeliegenden Annahmen werden anhand der Erfahrungen von alten Industrieregionen in einen scharfen Fokus gerückt. Wir untersuchen diese Themen mit Hilfe von empirischer Forschung über das aktuelle Schicksal von alten Industrieregionen in Westeuropa, für die wir Material aus der Eurostat- 
Datenbank nutzen. Aus unseren Ergebnissen geht hervor, dass die Erfahrungen unter diesen alten Industrieregionen unterschiedlich ausfallen. Dies wirft wiederum Fragen über die Rolle der verschiedenen nationalen Spielarten des Kapitalismus hinsichtlich der Gestaltung von regionalen Werdegängen sowie hinsichtlich der unterschiedlichen Mechanismen der in den jeweiligen Ländern geförderten regionalen Anpassung auf.

KEYWORDS:

Alte Industrieregionen

Regionale Leistung

Neuer Regionalismus

Regionalpolitik

Spielarten des Kapitalismus

JEL: N60; O18; P52; R11

Antiguas regiones industriales en Europa: una valoración comparativa del rendimiento económico

Kean Birch, Danny MacKinnon and Andrew Cumbers

\begin{abstract} fomentada en los países.

KEYWORDS:

Antiguas regiones industriales

Desempeño regional

El 'nuevo regionalismo'

Política regional

Variedades de capitalismo
\end{abstract}

En los recientes discursos académicos y políticos sobre el desarrollo regional en Europa se fomenta la expansión de las economías basadas en el conocimiento y las regiones de aprendizaje. Las suposiciones en las que se basa la nueva política regional se pueden examinar a fondo teniendo en cuenta las experiencias de las antiguas regiones industriales. Analizamos estos temas con ayuda de una investigación empírica del destino reciente de las antiguas regiones industriales en Europa del Oeste, basándonos en material de la base de datos Eurostat. Nuestros resultados destacan experiencias diversas entre estas antiguas regiones industriales. Esto plantea preguntas sobre el papel de las diferentes variedades nacionales de capitalismo a la hora de modelar las trayectorias regionales y los diversos mecanismos de la adaptación regional 


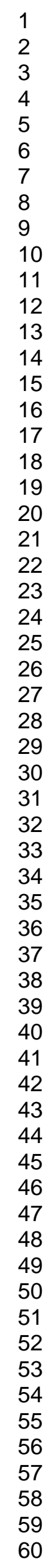

JEL: N60; O18; P52; R11 


\section{INTRODUCTION}

Recent academic and policy discourses on regional development in Europe are based upon a competitiveness-driven agenda that promotes the development of 'knowledge-based' economies and learning regions (see GARDINER et al., 2004; BRISTOW, 20005; BROWN, 2005). This is closely associated with the rise of a new model of regional policy which seeks to facilitate growth and innovation by harnessing local capacities and skills, in contrast to the 'old' regional policy prevalent in the 1960 s and 1970s (MORGAN, 1997; AMIN, 1999). British regional policy, for example, has shifted from the traditional emphasis on attracting inward investment towards the promotion of endogenous capacity as the government has adopted the perspective that $60 \%$ of regional GDP differences can be explained in terms of 'productivity' driven by five factors: skills, investment, innovation, enterprise and competition (HM TREASURY, 2001; HM TREASURY et al., 2003). Such national-level frameworks find additional support from the EU's Lisbon Agenda (EUROPEAN COMMISSION, 2000) which aims to make Europe "the most competitive and dynamic-knowledge-based economy with sustainable economic growth and greater social cohesion" (THE SAPIR GROUP, 2005, p.962). This new policy framework is, however, based upon a number of problematic assumptions in relation to its conceptualisation of productivity and the closely linked notion of 'competitiveness' (see FOTHERGILL, 2005; also KRUGMAN, 1996; KITSON et al., 2004; BRISTOW, 2005). In particular, it seems overly reliant upon mainstream economic sources which provide a "narrow base of evidence", embodying an ahistorical and asocial understanding of regional economic performance and development 
(FOTHERGILL, 2005, p.662). At the same time, this policy agenda also treats 'unequal regions equally' (MORGAN, 2006, p.189) in contrast to traditional regional policy which was explicitly targeted on less favoured regions, aiming to reduce disparities between core and periphery (MARTIN, 1989).

The assumptions underpinning the new regional policy are cast into sharp focus by the experiences of old industrial regions (OIRs) where the once-dominant heavy industries such as coal, steel and heavy engineering have undergone severe decline since the 1960s (CARNEY et al., 1980; HUDSON, 1994; BEATTY et al, 2005). The lack of concern with differences in industrial structure and divisions of labour, for instance both underlying issues in regional development research for decades - means that the policy focus on productivity ignores the "elementary observation that different industries and services have different levels of value added per head" (FOTHERGILL, 2005, p.663). Consequently, the problems of OIRs are not necessarily the result of internal deficits in productivity or competitiveness as prevailing policy discourses imply, but reflect the structural basis of their economies in terms of their historical over-reliance on a narrow group of heavy industries, only partly replaced in recent decades by routine services and foreign-owned manufacturing plants (HUDSON, 1994). Blighted by the prolonged decline of traditional sectors and lacking the capital, technological and labour assets of more dynamic cities and regions, OIRs face some important dilemmas of adaptation.

There is now an extensive literature on economic adjustment and renewal in OIRs, focusing particularly on the adjustment strategies and experiences of key organisations and firms (PIKE, 2001; CHAPMAN et al., 2004; TÖDTLING and 
TRIPPL, 2004; HUDSON, 2005a). Much of this takes the form of single region-case studies, providing valuable insights into processes of change. Alongside this 'intensive' research, however, there is still a need for more 'extensive' studies of the economic and social performance of different regions, providing a clearer comparative picture of patterns of adaptation (SAYER, 1992; RODRIGUEZ-POSE, 1998b; DUNFORD AND GRECO, 2006). ${ }^{1}$ With this in mind, this paper provides a preliminary account of economic and employment performances in OIRs in Western European countries since the mid-1990s, focusing on basic quantitative measures of change. In so doing, our purpose is as much to raise issues and questions for further research as it is to provide definitive conclusions. Our analysis is focused on OIRs in four of Western Europe's largest economies: France, Germany, Spain and the UK, drawing upon material from the Eurostat database. Following a review of the recent literature on regional development and path dependency, we compare different performance indicators, namely gross domestic product (GDP) for 1996-2003 and then employment trends for 1996-2005. This reveals significant national and regional variations in performance. We then unpack employment performance across the different regions by focusing upon the different components of employment change before concluding by emphasising the need to consider the relationship between regional processes of adaptation and national institutional frameworks.

\section{INSTITUTIONS, ECONOMIC PERFORMANCE AND OLD INDUSTRIAL REGIONS}




\section{Regional and National Institutions}

The so-called 'new regionalism' in economic geography and regional studies is concerned with the role of social and institutional conditions within regions in shaping regional performance and development (e.g. AMIN and THRIFT, 1994; MORGAN, 1997; STORPER, 1997; LOVERING, 1999). ${ }^{2}$ This understanding of regional development is broadly shared by the new model of regional policy emphasised earlier (HUDSON, 1999). The 'new regionalism' emphasises the interaction between regional actors which leads to collective and endogenous cultures that constitute the socioeconomic basis for regional performance (AMIN, 1999). Thus regional economies are seen as more than a collection of individual firms each with its own set of internal rules and behaviours; rather they are enabling environments which provide benefits to regional firms as a consequence of the shared social and institutional assets - e.g. tacit knowledge, local conventions and trust - that are particular to specific places (STORPER, 1997). Whilst highly influential in focusing attention on regional action, the new regionalist literature perhaps moves too far in over-emphasising the regional scale at the expense of the national, laying particular emphasis on the endogenous capacity of regions to adapt to changing conditions.

Another influential strand of regional research is focused on adaptation in OIRs, informed by the related evolutionary concepts of path dependency and lock-in (DOSI, 1988; ARTHUR, 1989, 1999). The former emphasises how economic performance is shaped by the legacy of past decisions and events and the latter refers to a situation in which the weight of existing assets, cultures and practices has prevented successful 
regional adjustment. Following HUDSON (2005a), however, we prefer the notion of path contingency to the rather 'over-socialised' concept of path dependency (PECK, 2005, p.153), because it emphasises the open-ended nature of evolutionary processes and the capacity of actors and institutions to shape their own pathways in the light of changing economic conditions. In order to move beyond the simple binary of regional renewal versus regional decline (HASSINK, 2005), it is important to recognise the complexity and diversity of processes of regional evolution, generating a variety of outcomes (MARTIN and SUNLEY, 2006). In this context, MARTIN and SUNLEY (2006, p.419423) identify different mechanisms of regional adaptation or 'de-locking', involving the establishment of a new endogenous development path, the harnessing of heterogeneity among agents, institutions and social networks, the transplantation of new technologies or organisational forms from elsewhere, diversification into technologically related industries and the upgrading of existing industries (cf. CHAPMAN et al., 2004).

One of the limitations of both these strands of regional research is a neglect of links to other scales of activity, particularly in terms of how regions are embedded in national policy frameworks (MACLEOD, 2001; HUDSON, 2003; DUNFORD AND GRECO, 2006). Here, political economists argue that capitalism has "developed territorially specific forms in Europe" such as the Anglo-Saxon, corporate Rhineland, Scandinavian, and Southern Europe models suggested by HUDSON (2003, p.49-50). This literature on varieties or national systems of capitalism compares different countries in terms of the institutional constraints on economic performance and development (e.g. WHITLEY, 1996; HALL and SOSKICE, 2001; AMABLE, 2003). In their review of this literature, PECK and THEODORE (2007) highlight the shifting currents in these debates 
where the early focus on two capitalist models - Rhinish and Anglo-American - has given way to a more sophisticated and complex characterisation of national institutional frameworks. Such theories emphasise the difference between coordinated-market economies (e.g. Germany, Japan) and their "long-term, structural relationships" with the decentralised and short-termist liberal-market economies (PECK and THEODORE, 2007, p.736). Mutually reinforcing feedback between the constitutive institutional parts of these economic systems helps to position firm activity within an overall framework that explains the differences between economies. The later varieties of capitalism approach favoured by HALL and SOSKICE (2001) amongst others goes further in situating economies on a continuum between coordinated-market economies and liberalmarket economies in which institutions adapt to complement one another. Of more relevance to the discussion here, however, is the work of AMABLE (2003) who distinguishes between five types of capitalism: market-based, social democratic, Asian, continental European and South European.

AMABLE's model maps onto the countries under consideration in this paper, with the UK representing a market-based economy, France and Germany continental economies and Spain a Southern European one, although others distinguish between a corporatist German model and a statist French one (BOYER, 2001). The importance of systemic coordination and interaction implied by these models mean that the institutional elements of each national economy constrain the ability of firms and other social actors to adapt to changing economic conditions, leading to path dependency and lock-in (ARTHUR, 1989, 1999). It is important to recognise, however, certain limitations in terms of how the varieties of capitalism approach conceptualises economic performance. 
These concern its privileging of the national scale, which inevitably leads to a neglect of the role of regional institutional differences, and its failure, as a theory of constraint, to address the question of motivation or how institutions also enable action (see CAMPBELL, 1997; CAMPBELL and PEDERSEN, 2001). Beyond these differences in focus and emphasis, however, there are certain commonalities between the varieties of capitalism approach and the new regionalism. Firstly, they both effectively privilege the determining influence of institutional factors over economic ones in their account of territorial variation in the nature and performance of capitalism (MARTIN and SUNLEY, 1998; DUNFORD and GRECO, 2006). Secondly, they both effectively abstract a single spatial scale from the broader set of relations in which they are positioned and entangled, neglecting the links between regional and national factors.

Nonetheless, the varieties of capitalism approach suggests that regional performance will be shaped by the underlying differences in national institutional frameworks. We might hypothesise that different national institutional conditions, for example between the more market-driven approach of the UK, and the more statist and corporatist frameworks in France and Germany, might lead to different patterns of regional adaptation. In particular, the latter states have sought to build on existing regional assets and competences, promoting processes of diversification into related technologies and the technological upgrading of existing industries whilst the marketorientated approach of the UK has favoured the transplantation of new technologies and organisational practices into OIRs from outside through the attraction of inward investment (see MARTIN and SUNLEY, 2006). As such, greater variations in regional performance might be expected in the UK case, reflecting underlying differences in the 
absorptive capacity of regions to processes of transplantation (MARTIN and SUNLEY, 2006) and a national institutional framework which stresses factor mobility and price competition, encouraging uneven development between regions (DUNFORD and PERRONS, 1994).

\section{Regional Development Policy and Old Industrial Regions}

Regional policy in Europe has become increasingly complex in recent decades, operating as part of broader system of multilevel governance (HASSINK, 1996; STURM, 1998). Nonetheless, nationally-orchestrated regional policy frameworks remain central to regional development and performance. France, (West) Germany, Spain and the UK all adopted traditional regional policies focused on reducing spatial disparities, although important differences in focus and timescale were apparent. Regional policy was traditionally more centralised and had a longer historical pedigree in the UK and France than either Germany or Spain (CLOUT, 1986; ARMSTRONG and TAYLOR, 2004), although in the former cases powers over regional policy were devolved in the early 1980s and late 1990s respectively (JONES, 2001; HERRSCHEL and NEWMAN, 2002). OIRs such as the Ruhr, North East France, North East England and Wales generally received a substantial share of expenditure on regional aid in the 1970s and 1980s, focused on industrial conversion, retraining, attracting new investment, environmental renewal and urban regeneration (COOKE, 1995; TUPPEN and THOMPSON, 1994; DANIELCZYK AND WOOD, 2004). In the 1980s, however, the UK effectively reduced regional spending whilst other European countries like Germany and France doubled it 
(CLOUT, 1986; TONDL, 2001). As indicated above, policy approaches towards the conversion of OIRS in France and Germany have focused on diversification into new but related technologies as a key mechanism of 'de-locking' (see MARTIN and SUNLEY, 2006) while the attraction of inward investment continued to be of central importance for British OIRs such as North East England, Scotland and Wales (COOKE, 1995; HUDSON, 2005). ${ }^{3}$

Processes of devolution in France and the UK are part of a broader 'regionalisation of regional policy' whereby regional actors have taken on a more prominent role since the 1980s $(\mathrm{BOSCH}, 1995)$. Key regional actors in the different countries are the Lander (state governments) in Germany, the governments of the autonomous communities or regions in Spain, elected Regional Councils in France and unelected Regional Development Agencies in the UK as well as the devolved administrations in Scotland, Wales and Northern Ireland (see BUDD, 1997; STURM, 1998; JONES, 2001; RODRIGUEZ-POSE and GILL, 2004; MORGAN, 2006). The 'regionalisation of regional policy' is also bound up with the shift to the new 'endogenous' model of regional development policy emphasised earlier. Three key dimensions of this approach can be identified: an emphasis on the importance of training and skills development, a focus on innovation and on research and development as part of a shift towards a knowledge-based economy, and efforts to support the growth of smalland-medium-sized enterprises (SMEs) (MORGAN, 1997; AMIN, 1999).

The new regional policy has been adopted in most European countries since the 1980s, supported by various EU initiatives and programmes. Specific variations in emphasis and timing are apparent, however, partly reflecting how the new policies 
interacted with the national varieties of capitalism described earlier. In the case of training and vocational education, for instance, the success of Germany's corporatist model has been contrasted with the limitations of the market-led approach favoured in the UK since the 1980s (JONES, 1999; ERTL AND SLOANE, 2004). The latter was accompanied by significant decentralisation to the local level. Vocational training in France has become a key responsibility of Regional Councils since 1983, overcoming the traditional centrist approach and requiring considerable 'scalar' adjustment from other actors such as business and trade unions (BOYER, 2001). Regional authorities have also been active in innovation policies and SMEs initiatives with the German Lander, for instance, exercising more control of these areas in the context of national and EU programmes than other areas of regional policy such as regional aid and industrial restructuring (STURM, 1998).

Policies towards innovation and SMEs in different regions have involved support for technology transfer and research and development based on an interactive approach which fosters links between industry and research organisations (HUGGINS AND THOMALLA, 1995; MORGAN, 2004). Many OIRs have been particularly active in this area with North-Rhine-Westphalia, for instance, accounting for 60 per cent of the funds distributed by the German Ministry of Research and Technology between 1991 and 1994 (HUGGINS AND THOMALLA, 1995, p.22). The European Commission's Regional Innovation Strategies programme is also targeted on less favoured regions, with somewhat varying results (MORGAN, 2004). SMEs have been a focus of some innovation and technology initiatives whilst also attracting broader support for business development and marketing (HUGGINS AND THOMALLA, 1995). 
More generally, while traditional regional policy was associated with convergence between regions in the 1960s and 1970s, this stalled from the late 1970s as 'spatial Keynesianism' (MARTIN, 1989) gave way to the neo-liberal emphasis on national and regional competitiveness (DUNFORD AND PERRONS, 1994; AGNEW, 2000). Despite this general shift, stronger nationally-orchestrated policies for supporting the diversification and technological upgrading of OIRs have been maintained in statist and corporatist countries such as France and Germany, but less so in neo-liberal ones like the UK (COOKE, 1995). At the same time, the divergent regional adaptation 'paths' of diversification and transplantation indicated above have been supplanted with the common promotion of endogenous forms of regional adaptation over the last decade or so. Nonetheless, the influence of national political economies linked to different regional 'paths' may be expected to generate significant national differences in the performance of OIRs. In particular, neo-liberal models such as the UK may perform better than more corporatist economies like France and Germany in terms of GDP growth, but also foster lower quality and less stable forms of employment.

\section{DEFINING OLD INDUSTRIAL REGIONS}

In setting out to explore issues of performance in OIRs, our primary concern is with those regions that were at the vanguard of early industrialisation in the European economy, geared to the exploitation of coal and other raw materials. These regions were at the forefront of capitalist development in the period from 1840 to the 1920 s, a phase termed extensive accumulation (AGLIETTA, 1979). Subsequently, with the rise of 
Fordist mass consumption sectors and then post-Fordist high-tech manufacturing and services, in addition to increased foreign competition in traditional industries, these regions have become increasingly marginal to the capitalist economy, leaving them facing long term problems of adaptation (HUDSON, 1994). In this context, we are concerned with the economic performance of these regions in a context of further European integration and enlargement.

There are several problems to confront in defining old industrial regions (OIR) in Europe, particularly problems of sectoral definition and classification, the availability of data, different periods of industrialisation, and subsequent 'peaks' in industrialisation in different countries (see TOWNSEND, 1997; SADLER, 2000). Our approach is informed by WILLIAMS'S (1992) reworking of regional typologies from the early 1980s. This separates regions into areas of slow and rapid capital accumulation, based upon a timeframe between the mid 1970s and early 1980s - the key period of economic crisis that has faced Europe's OIRs since the end of the Second World War. In a more recent classification, RODRÍGUEZ-POSE (1998a) provided an updated definition based on nationally weighted GDP and mean annual growth that identifies a number of the similar regions (see also RODRÍGUEZ-POSE, 1998b). This approach places some widelyrecognised OIRs in an intermediate position, however, although this appears to reflect the use of a larger regional scale (NUTS1).

Informed by these different approaches, we have opted for a relatively 'tight' definition of OIRs based upon old mining areas. While this excludes some regions based on the textiles, shipbuilding and engineering industries that could also be regarded as OIRs, it provides for a stronger degree of comparability between similar regions in 
different countries. At the same time, coal production was, of course, associated with the development of other heavy industries in many regions, particularly iron and steel. Our definition of OIRs covers many of the worst economic 'black spots' across Western European countries during the 1980s and 1990s, including the Ruhr and Saar regions of Germany, North-east France, the Basque region of Spain and the British coalfields (see BEATTY et al 2005; WILLIAMS, 1992, p.250).

The geographical scale of the data presented in the remainder of the paper is based upon NUTS2 designations (Table 1 and Figure 2). Although these NUTS2 designations are not ideal for our purposes - for example, Munster and West Wales and the Valleys include large rural areas - this level is more consistent with our 'tight' definition of OIRs than larger NUTS1 region (for example, Scotland) which would contain more extensive non-industrial areas. Avoiding the problem of using too large a regional designation, these NUTS 2 regions represent the closest area designations which also provide consistent data for the time period we are considering.

<Insert Table 1 here>

$<$ Insert Figure 1 here $>$

All the data in the following analysis was drawn from Eurostat Regional Data from 1996 until the most recent period available. This represents the furthest back that it is possible to go using Eurostat data at the NUTS 2 level for these OIRs and the most upto-date data available for all the indicators at the time of the data collection. The specific 
indicators for economic performance - e.g. GDP and GDP (PPS) - were derived from the Economic Accounts datasets, whilst the indicators for employment performance were derived from the Science and Technology datasets to provide consistency in the comparison of data on total employment and other employment categories (e.g. hightech, low-tech, manufacturing, services etc).

\section{AGGREGATE TRENDS IN REGIONAL ECONOMIC PERFORMANCE}

\section{Comparing Economic Performance}

In relation to economic performance, measured by change in gross domestic product (GDP), there is a clear pattern of strong growth in British OIRs over the period 1996 - 2003, well above the EU average, largely related to strong growth in the national economy as a whole (Figure 2). The worst performing regions were those in Germany, reflecting the weak performance of the German economy following reunification and the difficulties of absorbing the much poorer eastern Lander (EUROPEAN COMMISSION, 2007), although French regions also performed below the EU average. ${ }^{4}$ Thus, the faster growth of the UK model of market-orientated capitalism compared to the German corporatism and French statism is reflected in the performance of their respective OIRs. The difference in economic performance between states and OIRs is reduced significantly, however, when GDP is measured in terms of Purchasing Power Standards (PPS). ${ }^{5}$ This brings the UK closer to France and Germany, (presumably reflecting the higher costs of living in the former), making Spain and Pais Vasco the strongest 
performers (Figure 3). Furthermore, the difference between the highest and lowest regional changes is reduced from around an eight-fold difference (69 versus 9) to around a three-fold difference (55 versus 19).

$<$ Insert Figure 2 here $>$

$<$ Insert Figure 3 here>

Three key observations can be made in relation to this GDP data. First, it indicates that regional trends are strongly linked to national economic performance, an important link that has been largely overlooked by the 'new regionalism' (HUDSON, 1999; DUNFORD and GRECO, 2006). Second, in most cases, the performance of OIRs is weaker than that of the national economy, reflecting the ongoing challenge of structural conversion in such regions. The two main exceptions here are the German regions of Dusseldorf and Munster. Third, at the same time, there is evidence of important regional variations in the context of national economic change, pointing to the role of regionallyspecific factors. Such variations in performance between OIRs are most pronounced in the British case, supporting and extending the findings of BEATTY et al., (2005) which indicate that certain coalfield regions such as South Yorkshire and Northumberland, Tyne and Wear have out-performed others like South Wales since the mid-1980s. This also provides some initial support for the earlier suggestion that the UK's neo-liberal model would encourage greater variation in performance by placing more emphasis on the 
endogenous capacities of regions to respond to processes of transplantation through the attraction of inward investment (MARTIN and SUNLEY, 2006).

The next indicator we considered was employment change between 1996 and 2005. A general upturn in the fortunes of Europe's OIRs since the mid-1990s is apparent, in line with BEATTY et al's (2005) commentary on the UK coalfield regions, although the best performing OIRs are in France and Spain (see Figure 4). Nationally, the UK performs less well relative to other countries, particularly France, for employment change than GDP, even when the later is expressed in terms of PPS. Interestingly, while total employment rose more than the national rise in some French and German OIRs, this was the case for only three of the British OIRs (South Yorkshire, Derbyshire \& Nottinghamshire and West Wales). The performance of the remaining five was below the national average and total employment actually declined in two UK regions - Tees Valley \& Durham (-0.23\%) and Lancashire (-1.07\%) - during this period.

$<$ Insert Figure 4 here $>$

These figures are obviously crude, making no attempt to relate employment change from 1996 to 2005 to the scale of job losses in traditional industries since the 1970s. BEATTY et al (2005), provide an assessment of this for coalfield regions in England and Wales, providing evidence of significant recovery, particularly since the mid-1990s, but also of a continuing employment shortfall in some regions, much of it amounting to 'hidden unemployment' in the form of increased numbers claiming incapacity benefit in particular. There is some evidence that this hidden unemployment in 
British OIRs is partly balanced by higher official unemployment figures in French, German and Spanish OIRs. ${ }^{6}$

This data provides further support for the important link between trends in economic performance at the regional and national scales (HUDSON, 1999). In contrast to the GDP data, however, there is some evidence of French regions out-performing their British counterparts, suggesting that the traditionally more interventionist culture of French capitalism may offer benefits compared to the more deregulated and flexible economy of the UK in relation to aggregate employment as opposed to GDP. The fact that the German OIRs with their highly regulated and advanced training systems performed worse than some British OIRs in terms of employment creation would seem to reflect the constraining effects of a weak national economy, in addition to the structural challenges facing OIRs themselves. At the same time, there does not seem to be any clear relationship between economic performance and regional autonomy (see RODRIGUEZPOSE and GILL, 2004) with some French and English regions, which have lower levels of devolved power, performing better than the German OIRs. Indeed, the contrast between the performance of most English and German OIRs, particularly in terms of GDP, suggest that national economic growth is a more important influence than the level of regional autonomy, although this is not to discount the importance of regional initiatives, as indicated by the employment performance of regions such as Nord-Pas-DeCalais and Munster. ${ }^{7}$ In this context, a second cut at regional employment is required that begins to get beneath the aggregate figures presented here in order to explore changing components of change and what these reveal about regional performance. 


\section{UNPACKING EMPLOYMENT PERFORMANCE}

\section{Manufacturing Employment Change}

The figures for manufacturing employment change in the OIRs provide additional support for the link between national and regional economic trajectories, revealing more pronounced differences between individual countries and their regions than the data on overall employment change (see Figure 5). Deindustrialisation is very much an ongoing process in the UK where Office of National Statistics figures indicate that more than a million manufacturing jobs have been lost since $1997 .{ }^{8}$ Accordingly, the OIRs which had the largest decreases in manufacturing employment were all in the UK with six out of eight regions losing more than the national average (-26\%): Tees Valley \& Durham ($36 \%$ ), Northumberland \& Tyne \& Wear (-37\%), Lancashire (-39\%), Derbyshire \& Nottinghamshire (-27\%), West Wales \& the Valleys (-31\%), and South Western Scotland $(-41 \%)$. The German OIRs and Lorraine also experienced a fall in manufacturing employment, although these were less severe than in the UK. Pais Vasco and the other two French regions experienced increases, out-performing their national economies in this respect. The fact that some OIRs in high-cost economies like France can register strong employment growth in manufacturing - at a time of increased global and European integration and competitiveness - undermines some of the more simplistic popular accounts of the inevitability of deindustrialisation and the flight of capital to low cost locations in Eastern Europe or the developing world. Here, the influence of national political economies appears particularly strong with the UK's neo-liberal model entailing 
a virtual abandonment of industrial policy in the early 1980s compared to the more interventionist manufacturing-orientated strategy pursued in France and Germany (AMABLE, 2003; HUDSON, 2003), linked to an emphasis on regional adaptation through diversification rather than transplantation (MARTIN and SUNLEY, 2006)

$<$ Insert Figure 5 here $>$

Using NACE categories, we have further broken down manufacturing employment into high-tech and low-tech activities. Employment change in high-tech (HT) and medium high-tech (MHT) manufacturing for the same period mirrors that for total manufacturing change with a marked discrepancy between the performance of UK OIRs and most of the other regions (see Figure 6). ${ }^{9}$ Pais Vasco and the French OIRs experienced increases in HT and MHT employment above the national level, with the former and Picardie performing particularly strongly, whereas all UK regions saw a significant decrease in such employment compared with the EU15 average. The latter seems to reflect the lack of commitment from the UK state to diversification into new and related manufacturing sectors, and the technological upgrading of existing ones, as opposed to the attraction of low value-added activities (see HUDSON, 2005a). In five regions this decrease was greater than the national fall, itself nearly a quarter (-24\%). In two German regions (Munster and Saarland) there were increases above the EU15 and national trends, whilst in two other regions there were decreases, particularly marked in Arnsberg (-32\%), with a more marginal employment decline in the Dusseldorf region ($9 \%)$. 
$<$ Insert Figure 6 here $>$

For employment change in low-tech (LT) and medium low-tech (MLT) manufacturing, there was a more consistent pattern of employment decrease across regions than with total or high-tech manufacturing (Figure 7$).{ }^{10}$ This accords with the concept of the new international division of labour which highlights the tendency for relatively low-tech manufacturing to move to low cost economies, a trend that has spread to routine services in recent years (FROEBEL et al., 1980; DICKEN, 2003). The main difference here is the weaker performance of the German OIRs, with the exception of Arnsberg, and two French regions. In addition to reflecting the fortunes of the national economy, the higher propensity of the German regions to lose such employment may reflect their closer proximity to lower-cost regions in Central and Eastern Europe (SMITH, 2002). Pais Vasco and Nord-Pais-de-Calais recorded an increase in such employment, although this was below the national average in this case. All UK regions had a decrease in employment, with the greatest being in South Western Scotland (-46\%). Six regions experienced greater falls than the national average suggesting that manufacturing employment in such regions has been more affected by processes of deindustrialisation than other regions which have been less reliant on traditional heavy industry; i.e. certain sectors have been hollowed out more thoroughly or rapidly than others (HUDSON, 2003).

$<$ Insert Figure 7 here $>$ 
Service Sector Employment Change

In contrast to manufacturing, employment in services is characterised by growth, averaging 23\% for the EU15 between 1996 and 2005 (Figure 8). This shift of employment from manufacturing to services, of course, represents a key structural trend shaping developed economies since the 1970s (EUROPEAN COMMISSION, 2007). Compared to manufacturing, there was greater convergence between the performance of the UK, France and Germany, while Spain experienced an increase of over twice the EU level, reflecting its very strong growth in total employment. At the regional scale, the best performers are again Pais Vasco and Nord-Pas-de-Calais while Lorraine is the weakest performer with an increase of only 6 per cent. Beyond these outliers, however, the fortunes of the OIRs and their national economies are fairly similar with limited variation between regions within the same state. Thus, while the strong link between nations and regions remains apparent, the general growth in service employment seems to outweigh any effects stemming from divergent national varieties of capitalism and approaches to the conversion of OIRs (HUDSON, 2003).

$<$ Insert Figure 8 here $>$

When service employment is disaggregated, a marked increase in high-tech knowledge-intensive services (KIS) is evident for many regions (see Figure 9). ${ }^{11}$ Most OIRs in Britain and France out-performed their national economy in this area as did all 
the German regions, although the differences were much lower for the latter. The general pattern of growth provides a marked contrast with the decline experienced by many regions, particularly in Britain and Germany, in high and medium-tech manufacturing (Figure 6). This not only reflects the higher growth of high-tech KIS compared to services in general in the EU in recent years (EUROPEAN COMMISSION, 2006), but also the success of several OIRs in attracting and developing high-value service activities. This is highly encouraging in the light of evidence that such employment remains strongly concentrated in capital-city regions such as Ile de France, London and Stockholm (EUROPEAN COMMISSION, 2006). At the same time, however, there is greater variation between OIRs, particularly the French and British ones, than is evident for overall service employment. The decline in high-tech KIS employment that occurred in Lorraine and South Western Scotland reinforces the generally weak employment performance of these regions. The growth of routine services (i.e. less KIS) was significantly lower with German regions generally having the lowest increases across the four countries, although their performance was again variable (see Figure 10).

$<$ Insert Figure 9 here $>$

<Insert Figure 10 here $>$

Total High-technology Employment Change

http://mc.manuscriptcentral.com/cres Email: regional.studies@fm.ru.nl 
For a final piece of analysis, we have compared employment change in high-tech activities (both manufacturing and services) across OIRs (Figure 11). A pronounced pattern of national and regional variation emerges with most British regions experiencing a decline of such employment, despite their relatively good performance in relation to service employment, indicating that this has been out-weighed by the decline of high-tech manufacturing employment. By contrast, Pais Vasco and two French regions perform well in relation to both national and EU15 averages, although Lorraine witnesses a slight decline, reflecting its poor performance in high-tech services particularly. Most German regions perform equal to or above the national average, although Arnsberg shows a significant decline.

This more integrated picture of high-technology employment change provides clearer evidence of national contrasts in employment change than our assessment of services. As such, the differences between distinct national political economies are apparent in relation to high-tech employment, something which seems to reflect the stronger orientation of French statism and German corporatism towards higher levels of investment, productivity and training related to manufacturing compared to the UK's more market-orientated approach (COOKE, 1995; AMABLE, 2003; ERTL and SLOANE, 2004). At the same time, regional variations point to the importance of other factors, not least geographical position. In the UK case, for instance, it is noticeable that the worst performing regions tend to be in the North of England, Scotland and Wales, compared to better performing ones in South Yorkshire and the Midlands (BEATTY et al., 2005). It is the former regions, however, that have been the primary beneficiaries of regional policies stretching back to the late 1920s (ARMSTRONG and TAYLOR, 2004). 
This is suggestive of the operation of a very strong degree of regional path dependency in the UK space economy, indicating a continuing distinction between a "post-industrial periphery' and a more accessible and diversified group of regions around the Midlands, reflecting a persistent North-South divide in prosperity (MARTIN, 1988).

$<$ Insert Figure 11 here $>$

\section{CONCLUSIONS}

Our aim in this paper was to highlight the uneven pattern of adaptation that old industrial regions are experiencing across Western Europe. This leads us to make four key observations in conclusion. First, national institutional structures and different favoured 'paths' of regional adaptation play an important role in shaping the fortunes of OIRs with the French, Spanish and German cases contrasting with the UK. In broad terms, the British OIRs perform better in terms of GDP growth and service employment, while their continental counterparts do better in retaining manufacturing employment. This reflects the contrast between the more interventionist policies adopted in France and Germany and the UK's more market-orientated approach, coupled with the emphasis on regional diversification and upgrading in the former cases and transplantation through the attraction of inward investment in the latter (MARTIN and SUNLEY, 2006). While a stronger commitment to manufacturing is characteristic of these continental varieties of capitalism (AMABLE, 2003; HUDSON, 2005a), in the UK the interests of manufacturing industry have generally lost out to those of the financial and business 
service sectors, leading to further deindustrialisation in OIRs and reinforcing the NorthSouth divide (MARTIN, 1988). Thus, this paper offers further quantitative evidence of the importance of national institutional arrangements in shaping regional performance (see HUDSON et al., 1997), in contrast to 'new regionalist' work which neglects the role of national states. Indeed, the relationship between regional and national factors is one key avenue for investigation, requiring both further quantitative analysis of performance and in-depth qualitative studies of adaptation processes.

Second, there is no simple correlation between regional performance and levels of regional devolution or institutional 'thickness' at the regional level (AMIN and THRIFT, 1994; RODRÍGUEZ-POSE and GILL, 2004, HUDSON 2005b). This paper suggests that the different types of performance uncovered relate more to different national institutional frameworks and the particular 'paths' of regional adaptation pursued than the role of regional institutions. At the same time, however, the aggregate analysis of this paper should not be used to dismiss the role of regional government entirely, highlighting the need for further in-depth research into this important issue. Third, the GDP data provides some support for the notion that greater regional variation would be evident in the UK, reflecting its more market-orientated approach to regional development, although this finding is complicated by a number of other influences. In particular, the pattern of variation among British regions echoes an earlier distinction between a lagging 'industrial periphery' and a better performing group of regions around the Midlands (MARTIN, 1988). This not only suggests that geographical factors such as location and accessibility have an important role to play in shaping process of adaptation, it also emphasises the 
historically entrenched nature of uneven development in the UK (RODRIGUEZ-POSE, 1998b; DUNFORD and GRECO, 2006).

Finally, the evidence presented here raises some important questions for further research in understanding the underlying processes of change. In addition to the relationship between regional and national factors and the influence of regional devolution, these concern the identification of key agents, processes and sites of regional adaptation, the meaning and significance of path dependency and the nature of the relations between existing regional assets and broader extra-regional networks. Here, our analysis points to the importance of interlocking processes of path dependency which seem to be characteristic of both the operation of national models of economic development and the adaptation of regional economies, although the evidence of regional variation presented in this paper suggests that there is greater scope for adaptation and change at this scale, recalling HUDSON's (2005) notion of path contingency. Indeed, examining interlocking processes of path dependency and contingency at the regional and national scales represents one key task for evolutionary economic geography (BOSCHMA and MARTIN, 2007), requiring a move beyond the case study approach of much existing research (see MARKUSEN 1999) by developing multi-method comparative analyses that are capable of accounting for the causal mechanisms at work (SAYER, 1992).

\section{ACKNOWLEDGEMENTS}


Earlier versions of this paper were presented at the 2005 CPPR Seminar Series and the 2005 Annual Regional Studies Association Conference. The authors would like to thank the participants at these events, the anonymous referees and journal editors for their helpful comments. The usual disclaimers apply.

\section{REFERENCES}

AGLIETTA, M. (1979) A Theory of Capitalist Regulation. London, New Left Books.

AGNEW, J. (2000) From the political economy of regions to regional political economy, Progress in Human Geography 24(1), 101-110.

AMABLE, B. (2003) The Diversity of Modern Capitalism. Oxford, Oxford University Press.

AMIN, A. (1999) An institutionalist perspective on regional economic development, International Journal of Urban and Regional Research 23, 365-378.

AMIN, A. and THRIFT, N. (Eds) (1994) Globalization, Institutions, and Regional Development in Europe. Oxford, Oxford University Press.

AMIN, A., MASSEY, D. and THRIFT, N. (2003) Decentring the Nation. A Radical Approach to Regional Inequality. London, Catalyst.

ARMSTRONG, H. and TAYLOR, J. (2004) Regional Economics and Policy, Oxford, Blackwell Publishers.

ARTHUR, W. B. (1989) Competing technologies, increasing returns and lock-in by historical events, Economic Journal 99, 116-131.

ARTHUR, W. B. (1999) Competing technologies and economic prediction, in 
MacKENZIE, D. and WAJCMAN, J. (Eds) The Social Shaping of Technology. Buckingham, Open University Press.

BEATTY, C., FOTHERGILL, S. and POWELL, R. (2005) Twenty Years On: Has the Economy of the Coalfields Recovered? Regional Studies Association International Conference, University of Aalborg, Denmark.

BOSCH, G. (1995) Industrial restructuring and further retaining in North RhineWestphalia, in COOKE, P. (Ed.) The Rise of the Rustbelt. London, UCL Press.

BOSCHMA, R. and MARTIN, R. (2007) Editorial: Constructing an evolutionary economic geography, Journal of Economic Geography 7, 537-548.

BOYER, R. (2001) French statism at the crossroads, in CROUCH, C. and STREECK, W. (Eds) Political Economy of Modern Capitalism. London, Sage.

BRISTOW, G. (2005) Everyone's a 'winner': problematising the discourse of regional competitiveness, Journal of Economic Geography 5, 285-304.

BROWN, G. (2005) Global Europe: full-employment Europe. London, HM Treasury.

BUDD, L. (1997) Regional government and performance in France, Regional Studies 31, $187-192$.

CAMPBELL, J. (1997) Recent Trends in Institutional Political Economy, International Journal of Sociology and Social Policy 17, 15-56.

CAMPBELL, J. and PEDERSEN, O. (2001) Introduction: The Rise of Neoliberalism and Institutional Analysis, in CAMPBELL, J. and PEDERSEN, O. (Eds) The Rise of Neoliberalism and Institutional Analysis. New Jersey, Princeton University Press. CARNEY, J., HUDSON, R. and LEWIS, J. (Eds) (1980) Regions in Crisis. London, Croom Helm. 
CHAPMAN, K., MacKINNON, D. and CUMBERS, A. (2004) Adjustment or renewal in regional clusters? A study of diversification amongst SMEs in the Aberdeen oil complex, Transactions of the Institute of British Geographers 29, 382-396.

CLOUT, H. (1986) Regional variations in the European Community. Cambridge, Cambridge University Press.

COE, N., HESS, M., YEUNG, H., DICKEN, P. and HENDERSON, J. (2004) 'Globalizing' regional development: a global production networks perspective, Transactions of the Institute of British Geographers 29, 468-484.

COOKE, P (Ed) (1995) The Rise of the Rustbelt. London, UCL Press

DANIELZYK, R. and WOOD, G. (2004) Innovative strategies of political regionalisation: the case of North Rhine-Westphalia, European Planning Studies 12, 191207.

DICKEN, P. (2003) Global Shift: Reshaping the Global Economic Map in the $21^{\text {st }}$ Century. Fourth Edition. Sage, London.

DOSI, G. (1988) Sources, procedures, and microeconomic effects of innovation, Journal of Economic Literature 26, 1120-1171.

DUNFORD, M. and GRECO, L. (2006) After the Three Italies: Wealth, Inequality and Industrial Change. Blackwell, London.

DUNFORD, M. and PERRONS, D. (1994) Regional inequality, regimes of accumulation and economic development in contemporary Europe, Transactions of the Institute of British Geographers New Series 19(2), 163-182. 
DUNFORD, M. and SMITH, A. (2000) Catching Up or Falling Behind? Economic Performance and Regional Trajectories in the 'New Europe', Economic Geography 76, 169-195.

ERTL, H. and SLOANE, P.E.F (2004) The Germany training system and the world of work: the transfer potential of the lernfeldkonzept. Berufs - und Wirtschspadagogik. bwp@ issue nr 7. http://www.bwpat.de/7eu/. Accessed 8 August 2007.

EUROPEAN COMMISSION (2000) The Lisbon European Council - An Agenda of Economic and Social Renewal for Europe. Brussels, The European Commission $\mathrm{DOC} / 00 / 7$.

EUROPEAN COMMISSION (2006) Employment in High Technology: Statistics in focus- Science and Technology. Brussels, The European Commission

EUROPEAN COMMISSION (2007) Fourth Report on Economic and Social Cohesion. Brussels, The European Commission

FOTHERGILL, S. (2005) A New Regional Policy for Britain, Regional Studies 39(5), $659-667$.

FROEBEL, F., HEINRICHS, J. and KREYE, O. (1980) The New International Division of Labour. Cambridge University Press, Cambridge.

GARDINER, B., MARTIN, R. and TYLER, P. (2004) Competitiveness, Productivity and Economic Growth across the European Regions, Regional Studies 38(9), 1045-1067.

GRABHER, G. (Ed.) (1993) The Embedded Firm: On the socioeconomics of networks. London, Routledge.

GRABHER, G. and STARK, D. (1997) Organizing Diversity: Evolutionary Theory, Network Analysis and Postcolonialism, Regional Studies 31, 533-544. 
HALL, P. and SOSKICE, D. (eds) (2001) Varieties of Capitalism: The Institutional Foundations of Comparative Advantage. Oxford, Oxford University Press.

HARVEY, D. (1999[1982]) The Limits to Capital. London, Verso.

HASSINK, R. (1996) Regional technology policies in the old and new Lander of Germany: cases studies from Baden-Wurttemberg in Thuringia, European Urban and Regional Studies 3, 287-304

HASSINK, R. (2005) How to Unlock Regional Economies from Path Dependency? From Learning Regions to Learning Cluster, European Planning Studies 13, 521-535.

HERRSCHEL, T. and NEWMAN, P. (2002) Governance of Europe's City Regions: Planning, Policy and Politics. London, Routledge.

HM TREASURY (2001) Productivity in the UK: The Regional Dimension. London, HM Treasury.

HM TREASURY, DTI and ODPM (2003) A modern regional policy for the United Kingdom. London, HMSO.

HUDSON, R. (1994) Institutional Change, Cultural Transformation, and Economic Regeneration: Myths and Realities from Europe's Old Industrial Areas, in AMIN, A. and THRIFT, N. (Eds) Globalization, Institutions, and Regional Development in Europe. Oxford, Oxford University Press.

HUDSON, R. (1999) What makes economically successful regions in Europe successful? Implications for transferring success from west to east. RGS-IBG Economic Geography Research Group: EGRG Working Paper 99/01.

HUDSON, R. (2003) European Integration and New Forms of Uneven Development, European Urban and Regional Studies 10(1), 49-67. 
HUDSON, R. (2005a) Rethinking change in old industrial regions: reflecting on the experiences of North East England, Environment and Planning A 37, 581-596.

HUDSON, R. (2005b) Region and place: devolved regional government and regional economic success. Progress in Human Geography 29, 618-25.

HUDSON, R., DUNFORD, M., HAMILTON, D. and KOTTER, R. (1997) Developing regional strategies for economic success: lessons from Europe's economically successful regions, European Urban and Regional Studies 4, 365-373.

HUGGINS, R. and THOMALLA, R. (1995) Promoting innovation through technology networks in North Rhine-Westphalia, in COOKE, P. (Ed.) The Rise of the Rustbelt. London, UCL Press.

KITSON, M., MARTIN, R. and TYLER, P. (2004) Regional competitiveness: An elusive yet key concept? Regional Studies 38(9), 991-999.

KRUGMAN, P. (1996) Pop Internationalism. London, MIT Press.

JONES, M (1999) New Institutional Spaces: TECs and the Re-making of Economic Governance. London, Jessica Kingsley.

JONES, M (2001) The rise of the regional state in economic governance: "partnerships for prosperity' or new scales of state power?, Environment and Planning A 33, 11851211.

LOVERING, J. (1999) Theory led by policy: The inadequacies of 'The New Regionalism', International Journal of Urban and Regional Research 23(2), 379-395.

MACKINNON, D., CUMBERS, A. and CHAPMAN, K. (2002) Learning, innovation and regional development: a critical appraisal of recent debates, Progress in Human Geography 26, 293-311. 
MACLEOD, G. (2001) New regionalism reconsidered: globalisation, regulation and the recasting of political economic space, International Journal of Urban and Regional Research 25, 804-829.

MARTIN, R. (1988) The political economy of Britain's North-South divide, Transactions, Institute of British Geographers NS 13, 389-418.

MARTIN, R. (1989) The new regional economics and the politics of regional restructuring, in ALBRECHTS, L., MOULAERT, F., ROBERTS, P. and SWYNGEDOUW, E. (Eds) Regional Policy at the Crossroads: European perspectives. London, Jessica Kingsley.

MARTIN, R. and SUNLEY, P (1998) Slow convergence? The new endogenous growth theory and regional development, Economic Geography 74, 201-227.

MARTIN, R. and SUNLEY, P. (2006) Path dependence and regional economic evolution, Journal of Economic Geography 6(4), 395-437.

MORGAN, K. (1997) The Learning Region: Institutions, Innovation and Regional Renewal, Regional Studies 31(5), 491-503.

MORGAN, K. (2004) Sustainable Regions: Governance, Innovation and Scale, European Planning Studies 12(6), 871-889.

MORGAN, K. (2006) Devolution and development: territorial justice and the NorthSouth divide, Publius: The Journal of Federalism 36, 189-206.

MUNDAY, M. (1995) The regional consequences of the Japanese second wave: a case study, Local Economy 10, 4-20.

PECK, F. and STONE, I. (1993) Japanese inward investment in the northeast of England: reassessing “Japanisation', Environment \& Planning C, Government \& Policy 11: 55-67 
PECK, J. (2005) Economic Sociologies in Space, Economic Geography 81(2), 129-175.

PECK, J. and THEODORE, N. (2007) Variegated capitalism, Progress in Human Geography 31(6), 731-772.

PIKE, A. (2001) Corporate Retreat and the Abandonment of Host Economies in the Era of the 'Globalisation' of Capital: The Case of ManufacturingCo in the North East Region of England, Capital and Class 74, 31-59.

PIORE, M. and SABEL, C. (1984) The Second Industrial Divide: Prospects for Prosperity. New York, Basic Books.

REHFELD, D. (1995) Disintegration and reintegration of production clusters in the Ruhr area, in COOKE, P. (Ed.) The Rise of the Rustbelt. London, UCL Press.

RODRIGUEZ-POSE, A. (1998a) Social Conditions and Economic Performance: The Bond Between Social Structure and Regional Growth in Western Europe, International Journal of Urban and Regional Research 22(3), 443-459.

RODRIGUEZ-POSE, A. (1998b) The Dynamics of Regional Growth in Europe. Oxford, Clarendon Press.

RODRIGUEZ-POSE, A. and FRATESI, U. (2004) Between Development and Social Policies: The Impact of European Structural Funds in Objective 1 Regions, Regional Studies 38(1), 97-114.

RODRIGUEZ-POSE, A. and GILL, N. (2004) Is there a global link between regional disparities and devolution?, Environment and Planning A 36, 2097-2117.

SADLER, D. (2000) Manufacturing industry, in GARDINER, V. and MATTHEWS, H. (Eds) The Changing Geography of the United Kingdom. London, Routledge. 
SAYER A, (1992), Method in Social Science: A Realist Approach. Second Edition. London, Routledge.

SMITH, A. (2002) Imagining geographies of the 'new Europe': geo-economic power and the new European architecture, Political Geography 21, 647-670.

STORPER, M. (1997) The Regional World. London, Guilford Press.

STURM, R. (1998) Multi-level politics of regional development in Germany, European Planning Studies 6, 525-536.

THE SAPIR GROUP (2005) An Agenda for a Growing Europe: The Sapir Report, Regional Studies 39(7), 958-965.

TODTLING, F. and TRIPPL, M. (2004) Like Phoenix from the Ashes? The Renewal of Clusters in Old Industrial Areas, Urban Studies 41(5/6), 1175-1195.

TONDL, G. (2001) Regional Policy, in ARTIS, M. and NIXSON, F. (Eds) The Economics of the European Union: Policy and Analysis. Oxford, Oxford University Press.

TOWNSEND, A. (1997) Making a Living in Europe. London, Routledge.

TUPPEN, J.N. and THOMPSON, I.B. (1994) Industrial restructuring in contemporary France: spatial priorities and policies, Progress in Planning 44, 99-172.

WHITLEY, R. (1996) Business Systems and Global Commodity Chains: Competing or Complementary Forms of Economic Organisation, Competition and Change 1(4), 411425.

WILlIAMS, A. (1992) The Western European Economy: A Geography of Post-war Development. London, Routledge. 
Figure 1: Map of Old Industrial Regions in the Largest European States

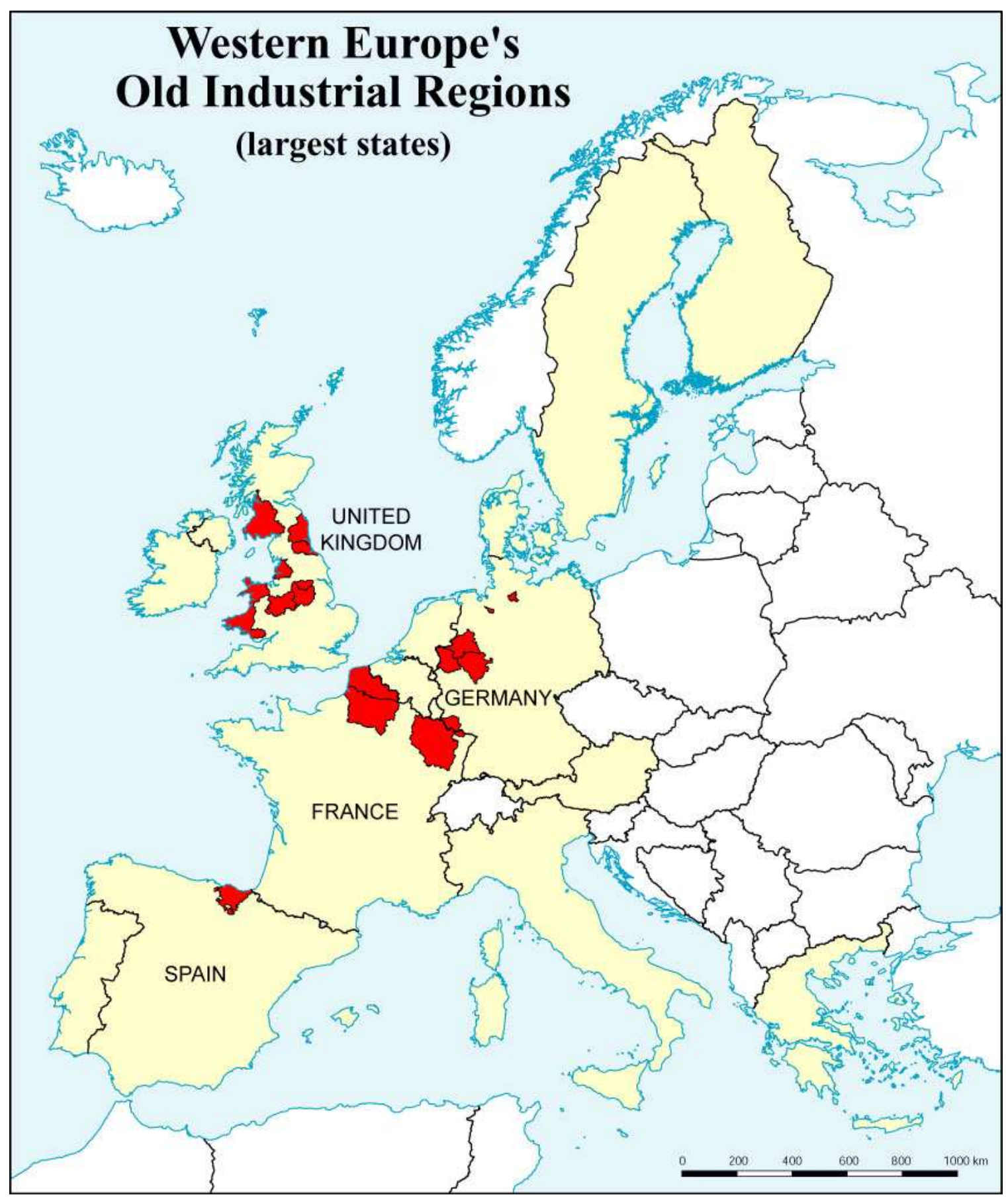

http://mc.manuscriptcentral.com/cres Email: regional.studies@fm.ru.nl 
Figure 2: Gross Domestic Product (GDP) \% Change 1996-2003

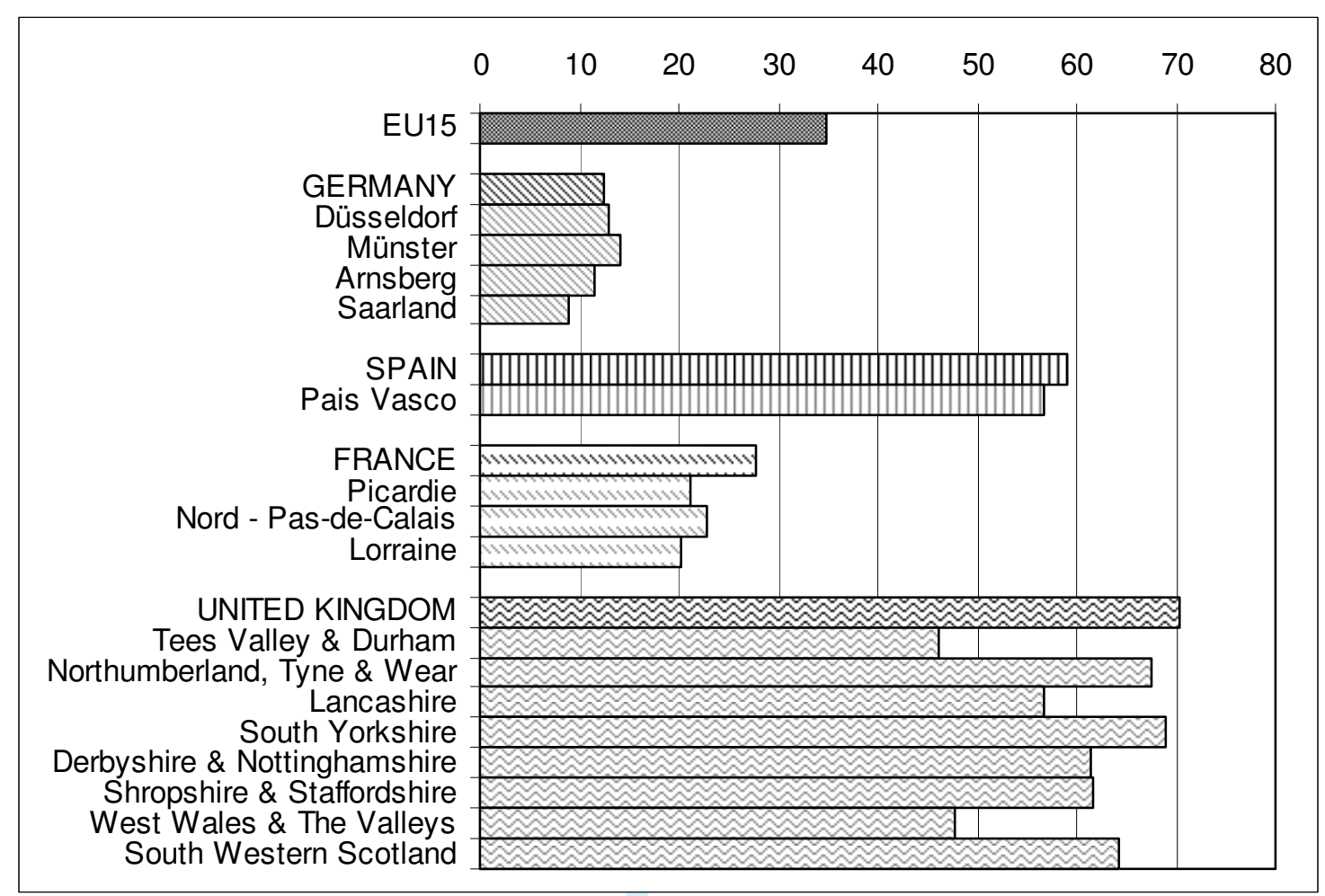

SOURCE: Eurostat, Regions - Economic Accounts

http://mc.manuscriptcentral.com/cres Email: regional.studies@fm.ru.nl 
Figure 3: GDP Purchasing Power Standards (PPS) \% Change 1996-2003

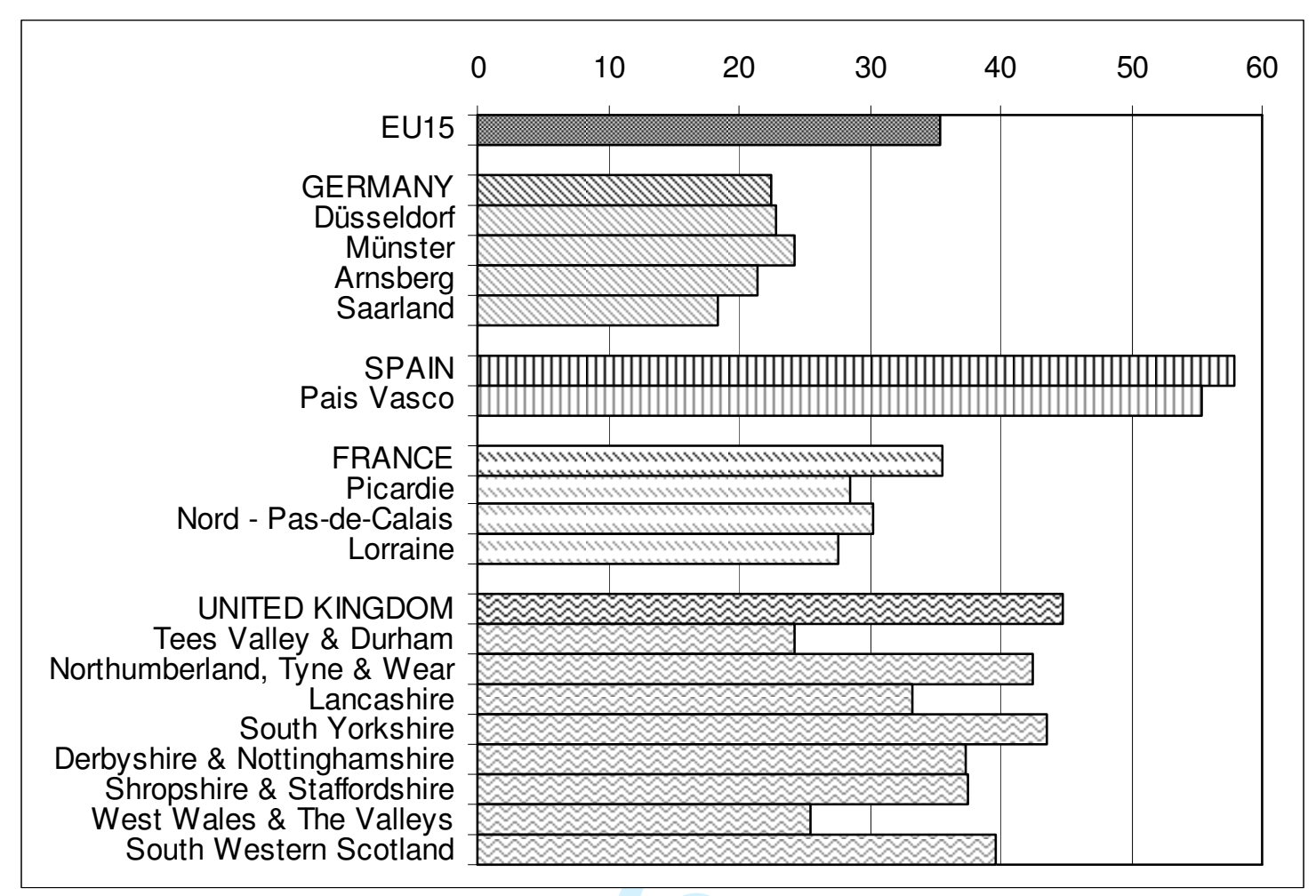

SOURCE: Eurostat, Regions - Economic Accounts 
Figure 4: National Index of GDP PPS Change 1996-2003

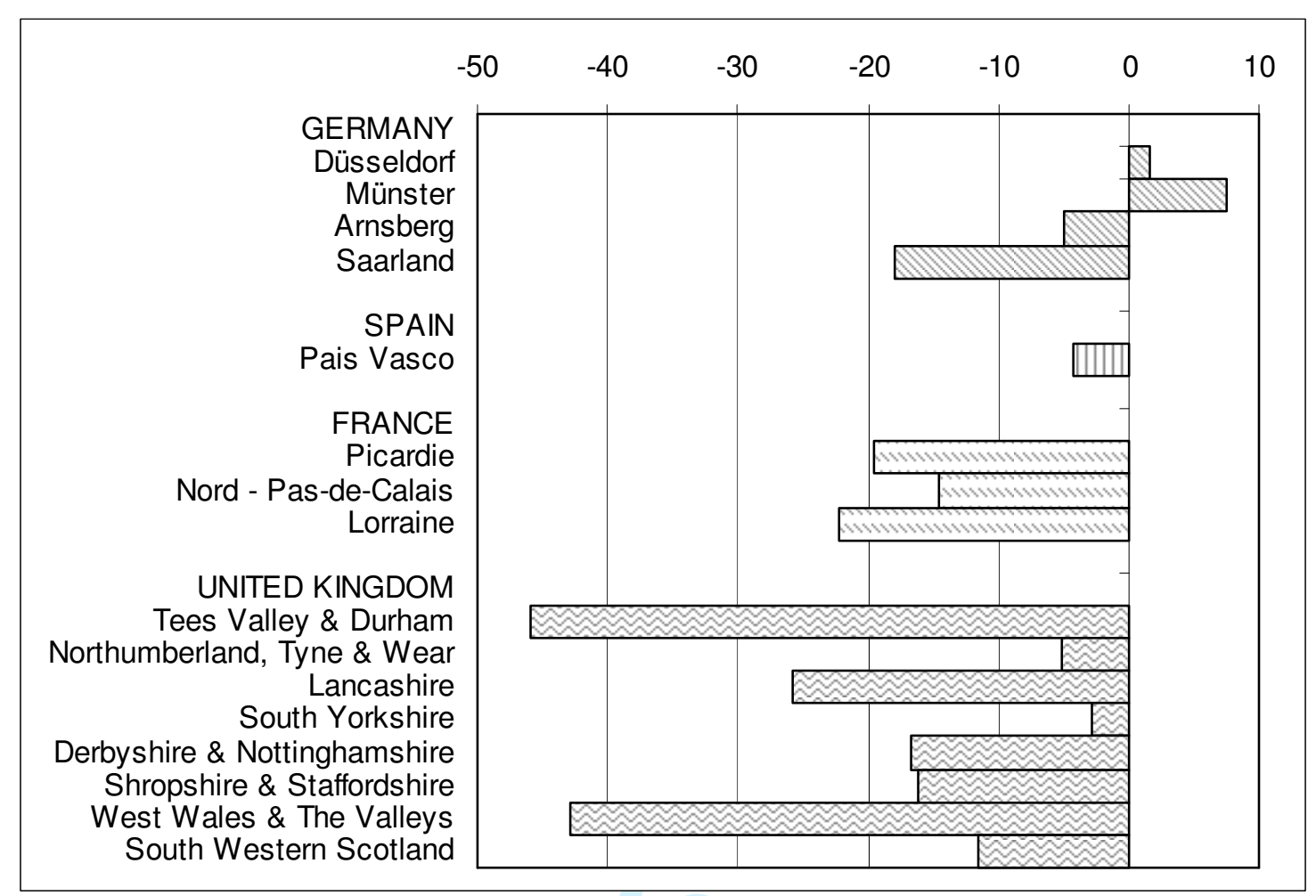

SOURCE: Eurostat, Regions - Economic Accounts

http://mc.manuscriptcentral.com/cres Email: regional.studies@fm.ru.nl 
Figure 5: Total Employment Change 1996-2005

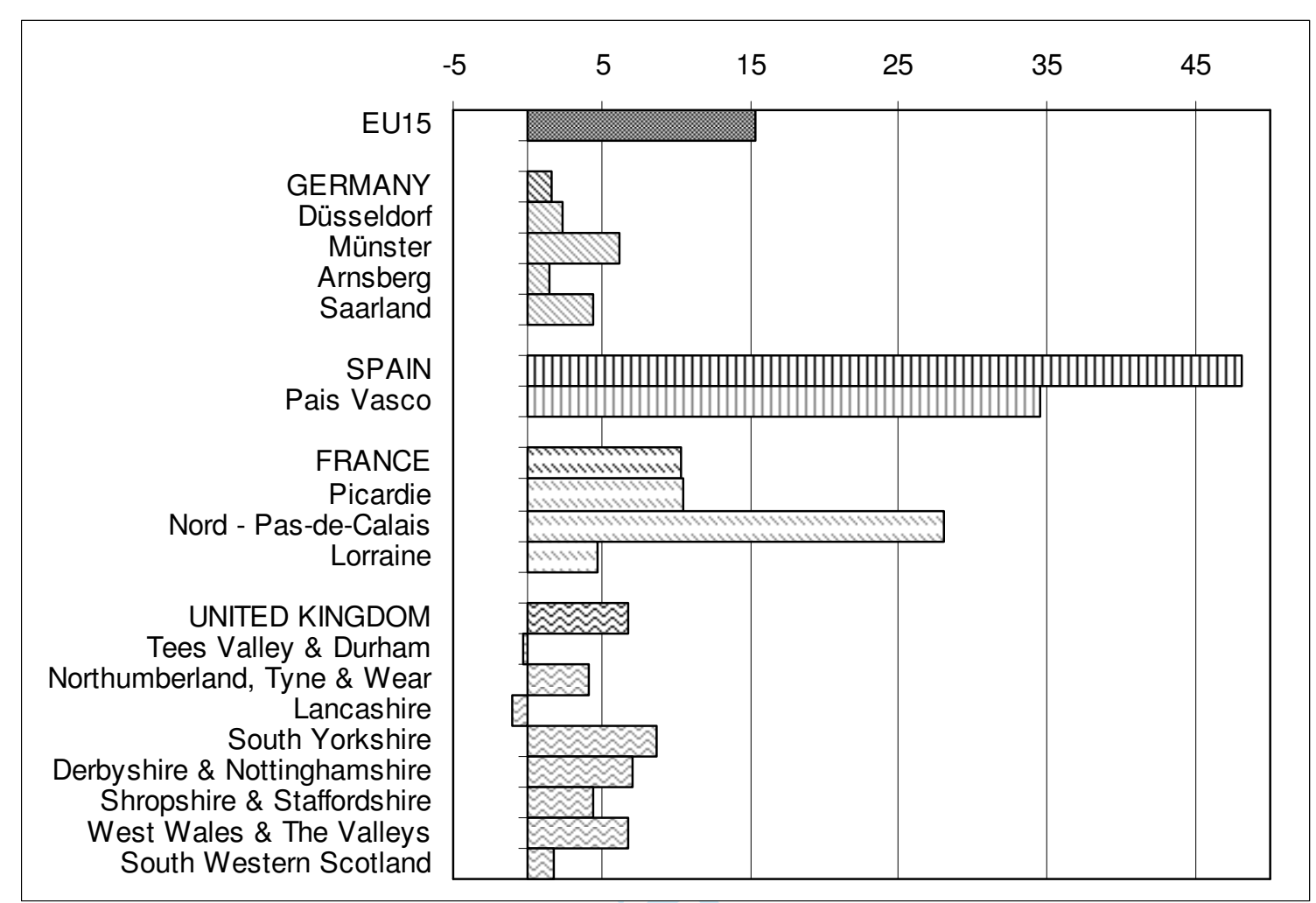

SOURCE: Eurostat, Regions - Science and Technology

http://mc.manuscriptcentral.com/cres Email: regional.studies@fm.ru.nl 
Figure 6: Manufacturing (NACE D) Employment Change 1996-2005

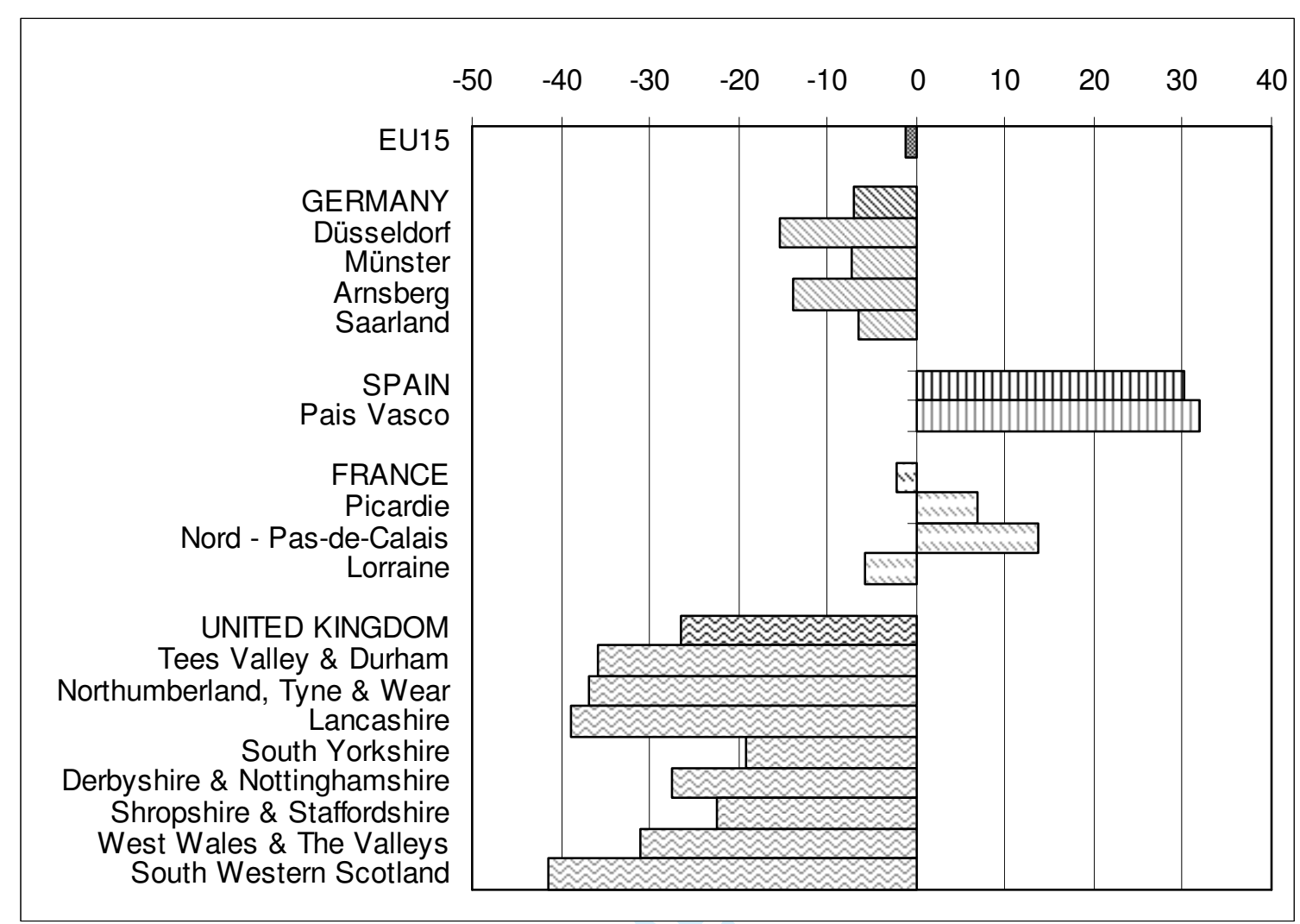

SOURCE: Eurostat, Regions - Science and Technology 
Figure 7: High-tech and Medium High-tech Manufacturing Employment Change 19962005

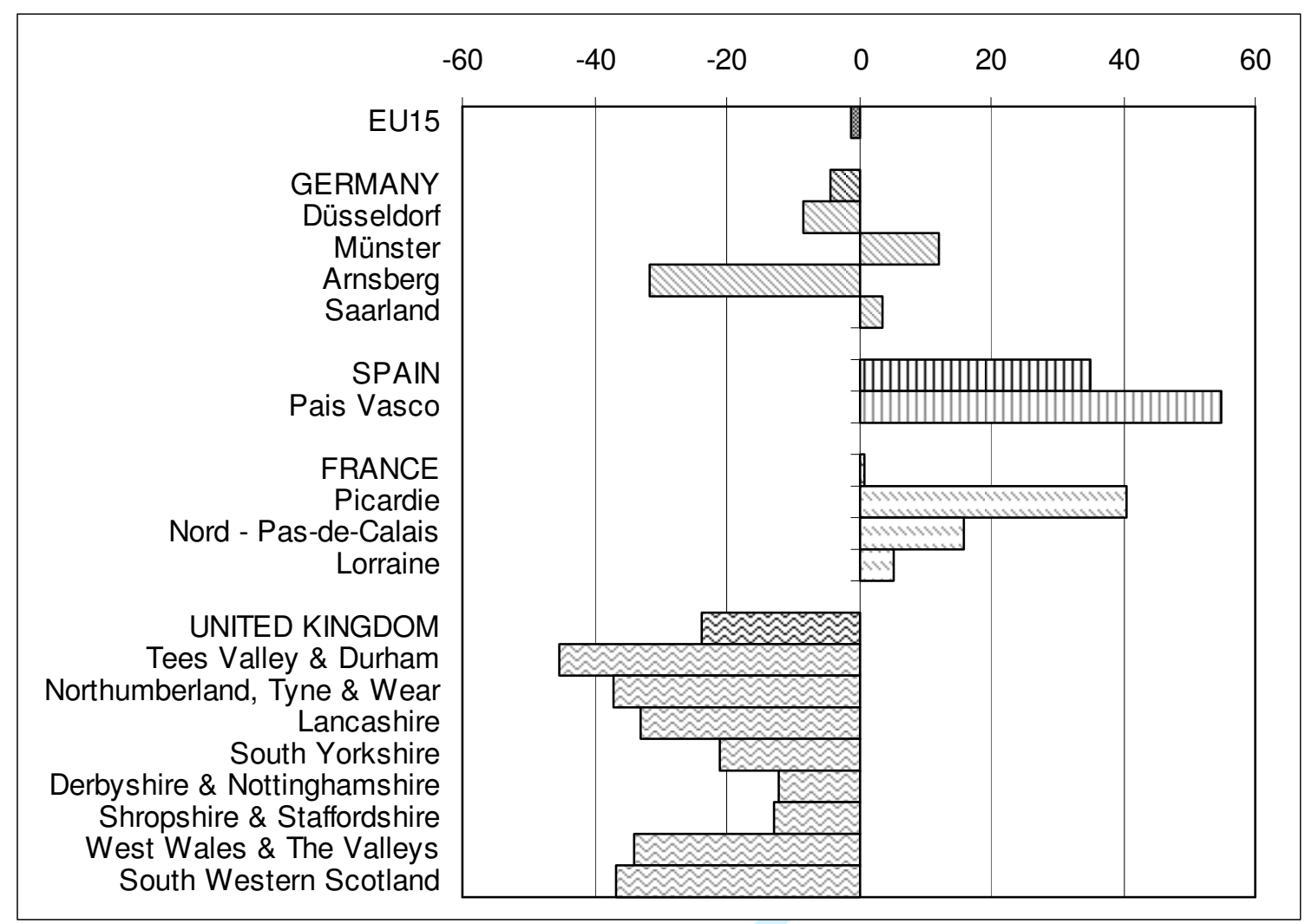

SOURCE: Eurostat, Regions - Science and Technology 
Figure 8: Low-tech and Medium Low-tech Manufacturing Employment Change 19962005

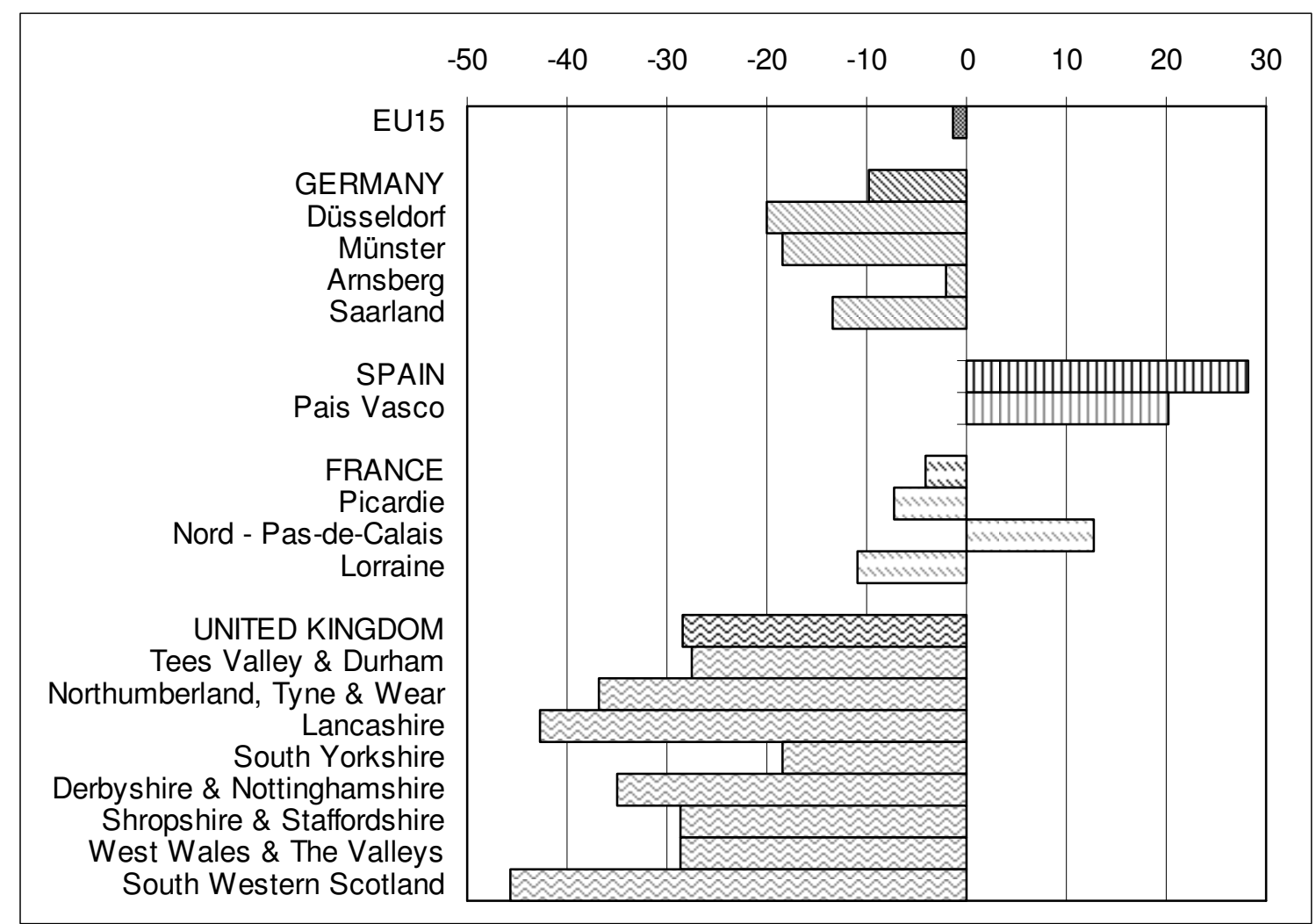

SOURCE: Eurostat, Regions - Science and Technology 
Figure 9: Services Employment Change 1996-2005

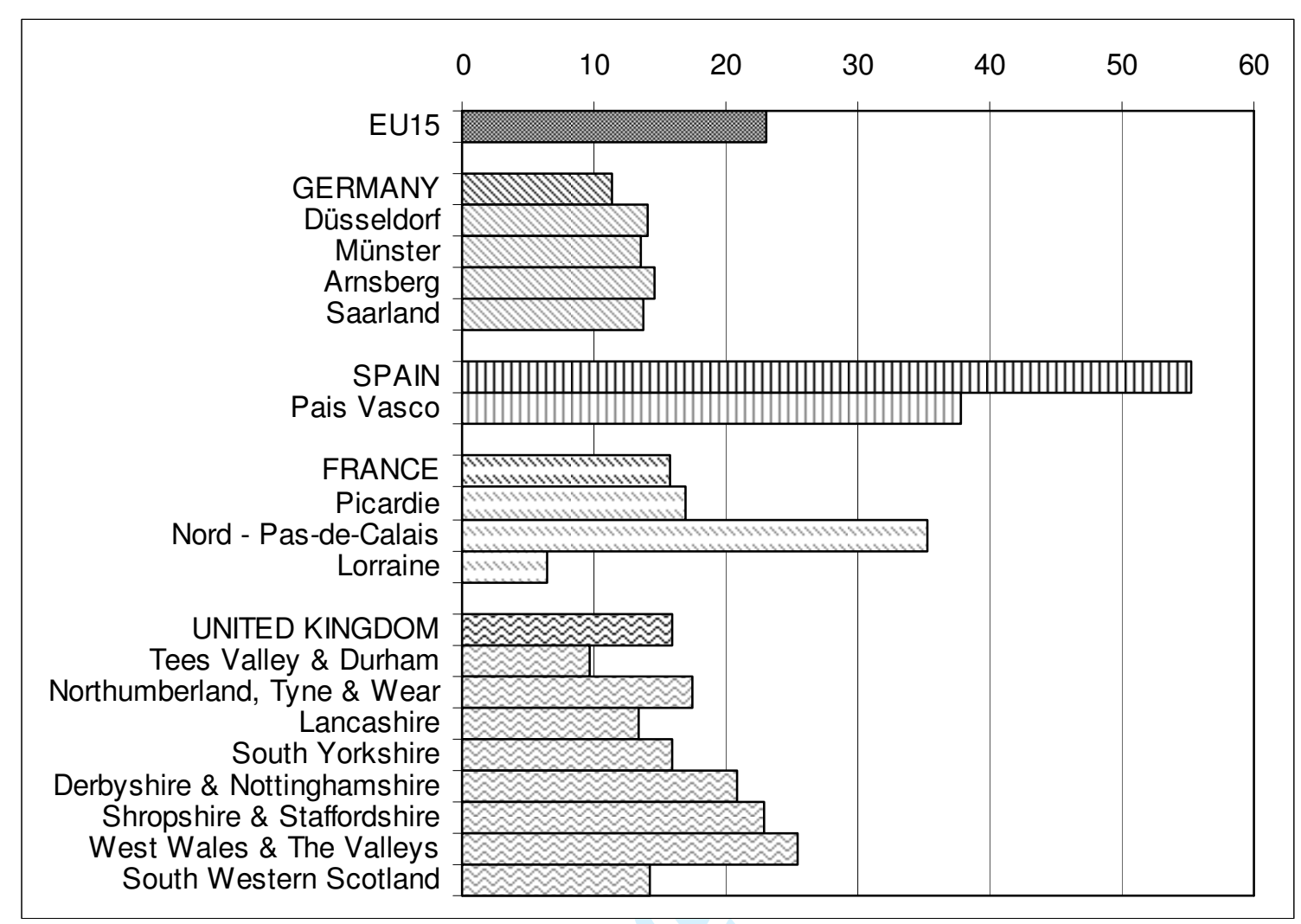

SOURCE: Eurostat, Regions - Science and Technology 
Figure 10: Hi-tech Knowledge Intensive Services Employment Change 1996-2005

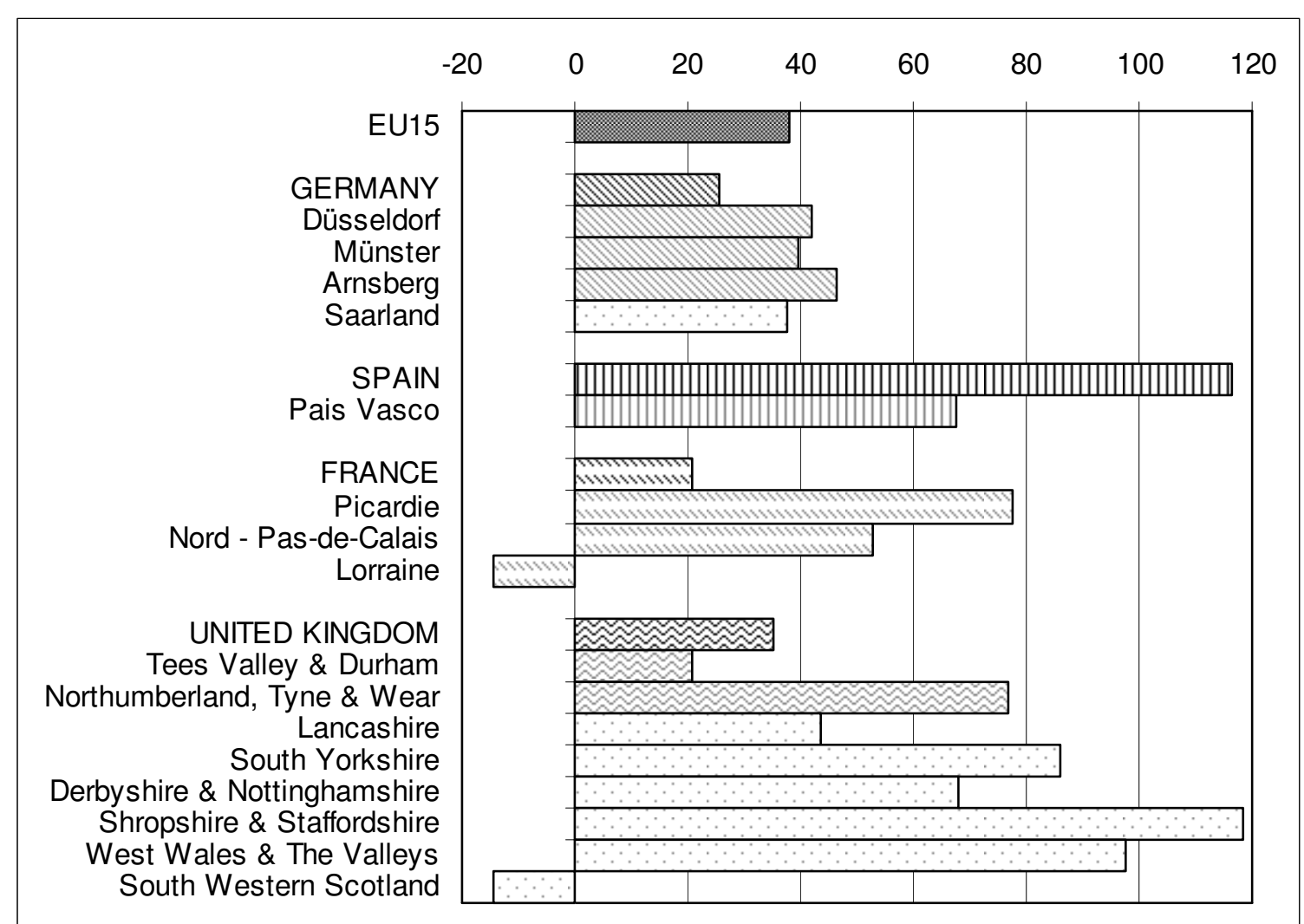

SOURCE: Eurostat, Regions - Science and Technology 
Figure 11: Employment Change in Routine Services (Less KIS) 1996-2005

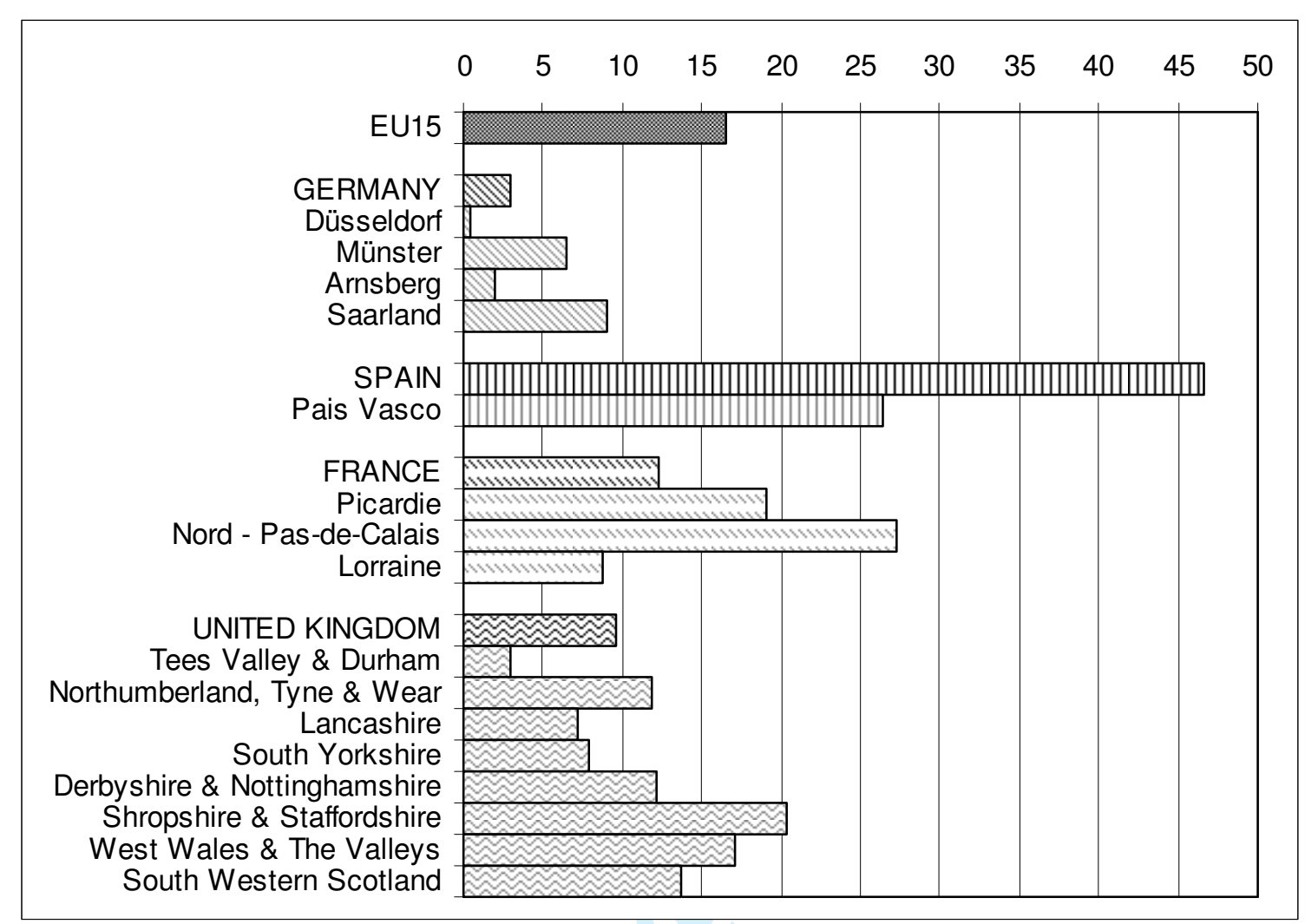

SOURCE: Eurostat, Regions - Science and Technology 
Figure 12: Total Hi-Tech Employment Change (Manufacturing and Services) 1996-2005

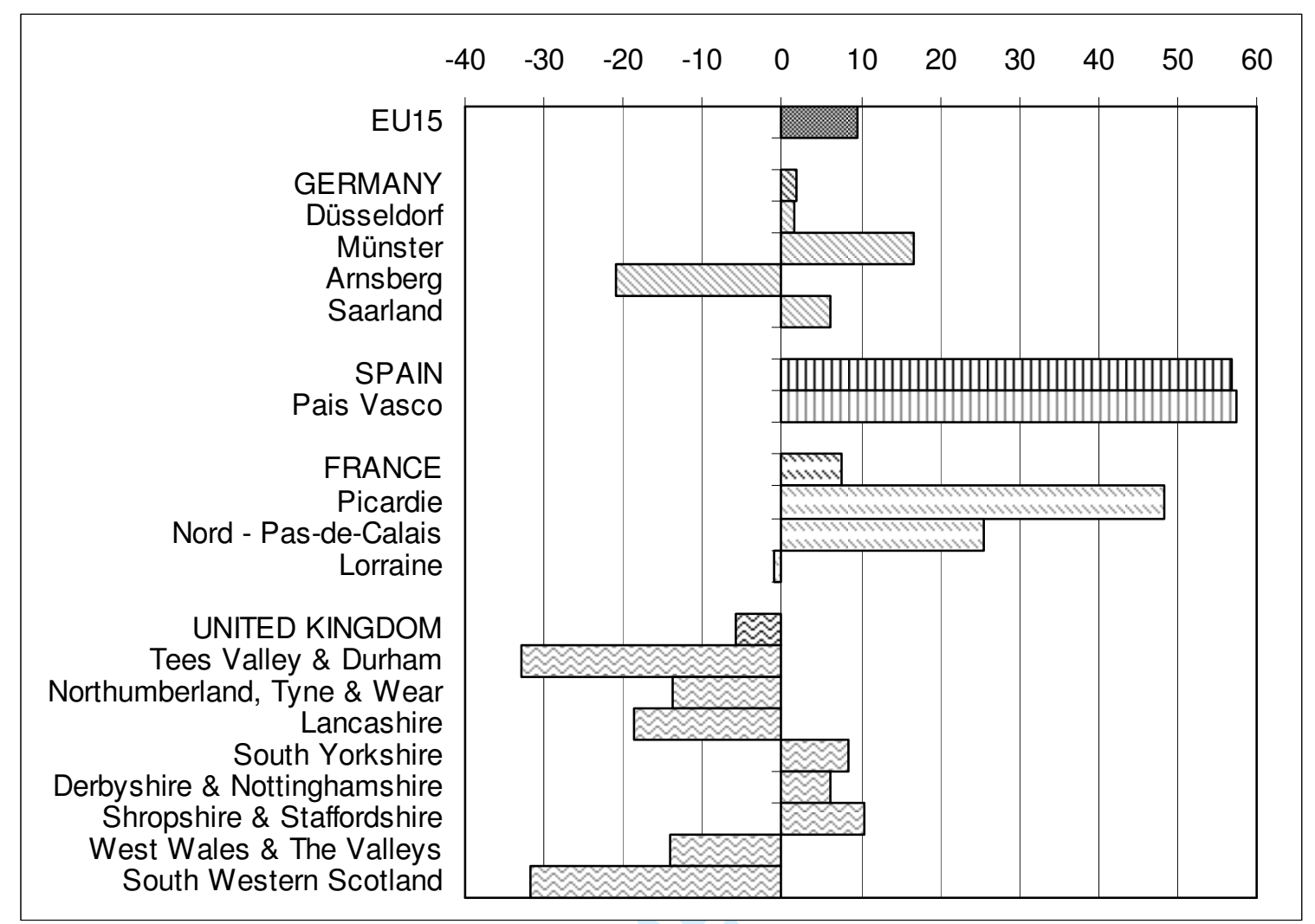

SOURCE: Eurostat, Regions - Science and Technology 
Figure 13: National Index of Total Hi-tech Employment Change 1996-2005

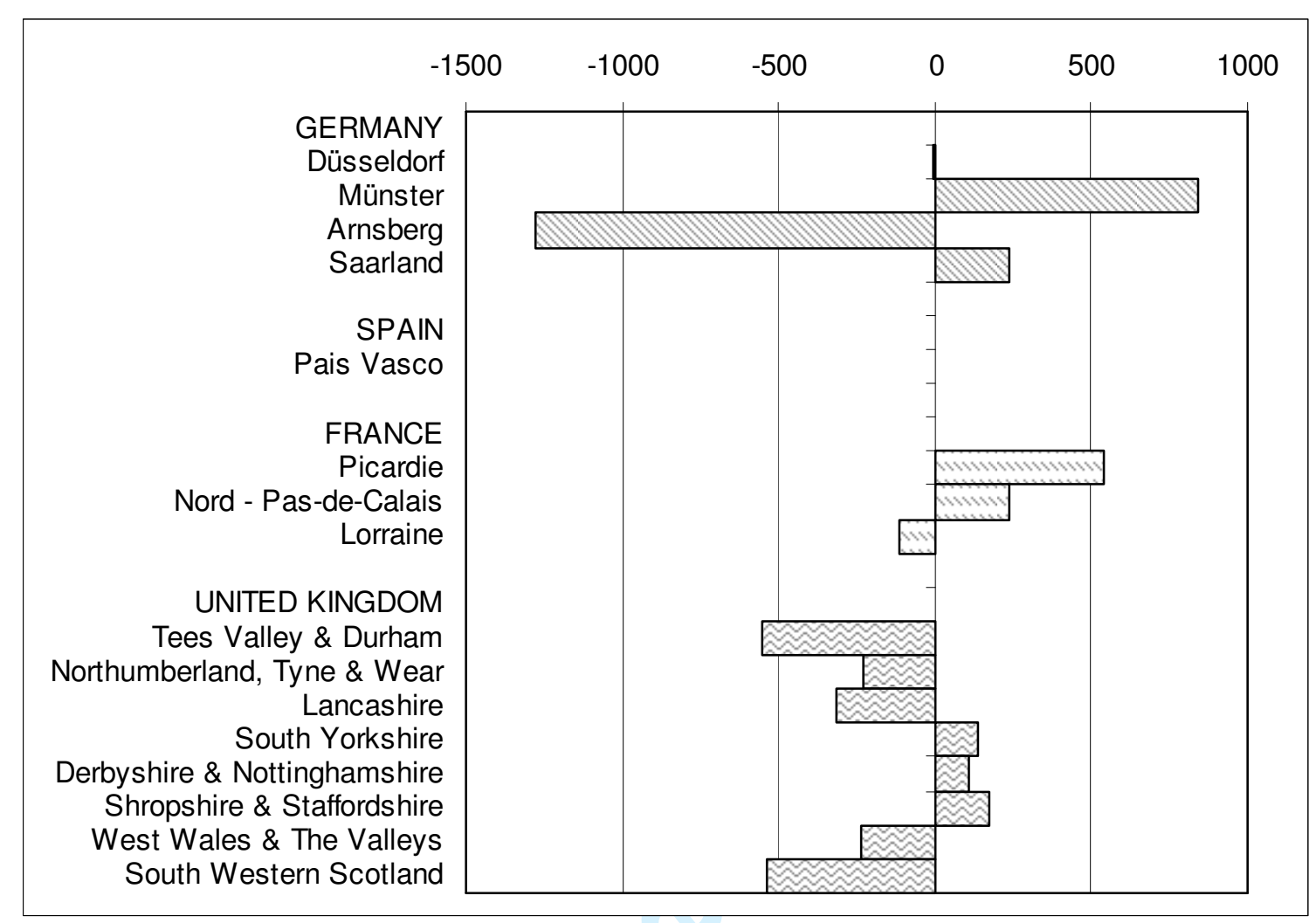

SOURCE: Eurostat, Regions - Science and Technology 
Table 1: European Old Industrial Region Designations

\begin{tabular}{lll}
\hline OIR Typology & NUTS2 Region & NUTS2 Code \\
\hline Ruhr & Düsseldorf & dea1 \\
& Münster & dea3 \\
& Arnsberg & dea5 \\
Saar & Saarland & dec0 \\
\hline North-east France & Picardie & fr22 \\
& Nord Pas-de-Calais & fr30 \\
& Lorraine & fr41 \\
\hline Basque country & Pais Vasco & es21 \\
\hline UK coalfields & Tees Valley \& Durham & ukc1 \\
& Northumberland, Tyne \& Wear & ukc2 \\
& Lancashire & ukd4 \\
& South Yorkshire & uke3 \\
& Derbyshire \& Nottinghamshire & ukf1 \\
& Shropshire \& Staffordshire & ukg2 \\
& West Wales \& The Valleys & uk11 \\
& South Western Scotland & ukm3 \\
\hline
\end{tabular}


${ }^{1}$ We prefer adaptation to the more commonly-used the term of adjustment since it emphasises the diverse ways in which economic actors and organisations respond to changing circumstances, reflecting heterodox notions of complexity, diversity and variety. Adjustment, by contrast, seems to reflect orthodox notions of convergence to market norms (GRABHER and STARK, 1997).

${ }^{2}$ We acknowledge that the term 'new regionalism' incorporates several distinct strands of research - in addition to associated policy developments - under a single overarching label (MORGAN, 2004). Ultimately, however, we maintain that the label is justified by the shared emphasis on the renewed importance of 'the region' as a scale of economic organisation under late capitalism (LOVERING, 1999; MACKINNON et al., 2002).

${ }^{3}$ The significance attached to inward investment is evident, for instance, in the hype surrounding Japanese investment in North East England and South Wales in the late 1980s and early 1990s (MUNDAY, 1995; PECK and STONE, 1993).

${ }^{4}$ The EU average for employment excludes Portugal because the data was unavailable from Eurostat.

${ }^{5}$ According to Eurostat, Purchasing Power Standards (PPS) "are a fictive currency unit that eliminates differences in purchasing power, i.e. different price levels, between countries."

${ }^{6}$ In 2003, the average unemployment rate for British OIRs was 5.5 per cent compared with 10.7 and 8.9 for French and German regions respectively (Source: Eurostat).

${ }^{7}$ The former is particularly known for its economic activism since the late 1970s (BUDD, 1997). 
8

See $\quad$ http://www.statistics.gov.uk/pdfdir/lmsuk0206.pdf

and

http://www.statistics.gov.uk/statbase/tsdtables 1.asp?vlnk=lms

${ }^{9}$ High-tech manufacturing involves aerospace (NACE 35.3); pharmaceuticals (24.4); computers, office machinery (30); electronics-communications (32); and scientific instruments (33). Medium high-tech consists of electrical machinery (31); motor vehicles (34); chemicals, except pharmaceuticals (24 excluding 24.4); other transport equipment (35.2, 35.4, 35.5); and non-electrical machinery (29) (Source: Eurostat).

${ }^{10}$ Medium low-tech manufacturing consists of coke, refined petroleum products and nuclear fuel (NACE 23); rubber and plastic products (25); non-metallic mineral products (26); shipbuilding (35.1); basic metals (27); and fabricated metal products (28). Low-tech covers other manufacturing and recycling $(36,37)$; wood, pulp, paper products, printing and publishing $(20,21,22)$; food, beverages and tobacco $(15,16)$; and textile and clothing $(17,18,19)$ (Source: Eurostat).

${ }^{11}$ Knowledge-intensive high-tech services include post and telecommunications (NACE 64); computer and related activities (72); and research and development (73) (Source: Eurostat). 